\title{
Resumos de Dissertações de Mestrado e Teses de Doutorado apresentadas na Faculdade de Medicina de Ribeirão Preto - USP de julho a setembro de 2010
}

\author{
Biologia Celular e Molecular
}

\author{
EFEITOS DE CLOROQUINA NA INFECÇÃO POR víRUS OROPOUCHE in vitro E in vivo
}

\author{
André Escremim de Paula \\ Orientador: Prof. Dr. Eurico Arruda \\ Dissertação de Mestrado apresentada em 19/08/2010
}

O vírus Oropouche (OROV) pertence à família Bunyaviridae, gênero Orthobunyavirus, e é a segunda causa mais frequente de arbovirose febril no Brasil. Além de causar surtos epidêmicos que acometem milhares de pessoas na região Amazônica, há potencial risco de disseminação do vírus para outras áreas do Brasil e da América do Sul. Apesar da sua relevância em saúde pública, não há terapia contra a febre do OROV. Cloroquina (CQ) é uma droga de baixo custo, baixa toxicidade, e há vasta experiência no seu uso clínico no tratamento de malária. CQ neutraliza o pH ácido de organelas intracelulares, inibindo os passos dependente de acidificação na replicação de vários vírus. Sabe-se que OROV entra em células hospedeiras por endocitose dependente de $\mathrm{pH}$ ácido. Desta forma, o presente estudo buscou avaliar o efeito antiviral de CQ em células HeLa e em infecção experimental de camundongos BALB/c recém-nascido. Nós mostramos que

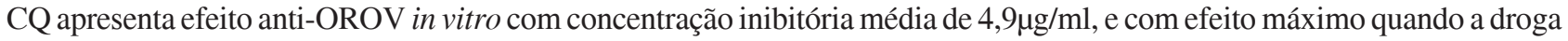
é adicionada $1 \mathrm{~h}$ antes e junto com o vírus. Para avaliar seu efeito in vivo, camundongos BALB/c recém nascidos tratados com CQ foram infectados OROV via subcutânea. O tratamento dos animais com $3 \mathrm{mg} / \mathrm{kg}$ de cloroquina resultou em discreto efeito antiviral. À medida que a dose da droga foi gradativamente aumentada, esse efeito se perdeu, e passou a ser prejudicial com o aumento da mortalidade dos animais tratados com $30 \mathrm{mg} / \mathrm{kg}$ de CQ. A quantificação da carga viral no cérebro dos animais avaliada por PCR em tempo real demonstrou que a maior mortalidade estava relacionada com maior replicação viral. Como OROV se replica no SNC de camundongos, o efeito de CQ foi avaliado in vitro em células SH-SY5Y originárias de neuroblastoma. Vimos que a droga não afetou a replicação viral, sugerindo que OROV pode entrar em neurônios por outro mecanismo que não endocitose dependente de $\mathrm{pH}$ ácido. Nossos resultados demonstram que CQ é ineficaz contra infecção experimental de OROV in vivo, e que se deve ter cautela quanto à extrapolação de resultados obtidos in vitro para situações in vivo. CQ é uma droga de uso frequente em áreas endêmicas de malária, que em grande parte coincidem com áreas endêmicas de OROV e de outros arbovírus que também causam doenças febris semelhantes à malária. Diante disso, torna-se importante investigar o efeito deletério da droga em infecções por OROV visando a esclarecer seu mecanismo.

\section{Clínica Cirúrgica}

\section{ESTUDO DA DISFUNÇÃO VÉSICO-URETRAL DECORRENTE DO DIABETES INDUZIDO POR ALOXANO EM RATAS: AVALIAÇÃO URODINÂMICA,M MORFOLÓGICA E AÇÃO DO CITRATO DE SILDENAFIL}

\author{
Ana Beatriz Gomes de Souza \\ Orientador: Prof. Dr. Haylton Jorge Suaid \\ Tese de Doutorado apresentada em 05/07/2010
}

Introdução: $O$ diabetes mellitus afeta 20,8 milhões de pessoas nos Estados Unidos. A cistopatia diabética é uma das complicações mais comuns do diabetes mellitus. Apresenta alta morbi-mortalidade com impacto importante sobre a qualidade de vida. Objetivo: avaliar o componente uretral na cistopatia induzido pelo diabetes mellitus e a ação do sildenafil sobre o mecanismo de relaxamento uretral em ratas com diabetes induzido por aloxano. Metodologia: Foram estudadas 38 
ratas divididas em 5 grupos: G1- 09 ratas com seis semanas de seguimento; G2- 06 ratas com seis semanas de seguimento e tratadas com citrato de sildenafil (1,0 mg/kg de peso); G3- 09 ratas com seis semanas a pós indução do diabetes por aloxano (40 mg/kg de peso); G4- 05 ratas com seis semanas após indução do diabetes por aloxano tratadas com citrato de sildenafil. G5- 09 ratas com 20 semanas após indução do diabetes por aloxano. Os animais foram submetidos à anestesia com uretana (1,25 mg/kg de peso) e avaliação urodinâmica através de cistometria e pressão uretral simultaneamente. Os parâmetros avaliados foram intensidade de contração vesical (IC), tempo de contração vesical (TC), tempo de enchimento vesical (TE), frequência (F), complacência vesical (F), pressão uretral durante a contração vesical (PUC), pressão uretral durante o enchimento vesical (PUE). O sistema de registro das pressões constitui-se do aparelho de urodinâmica Dynamed ${ }^{\circ}$, modelo Dynapack MPX-816 conectado a uma bomba de infusão contínua. Os dados foram analisados através do software UroMaster II. Após isto, foram seccionados bexiga e uretra fixados para posterior análise histológica. Os animais foram submetidos à eutanásia sob anestesia. Resultados: TC1 vs TC3 p=0.0278; PUC1 vs PUC3 p=0.0121; PUC5 vs PUC1 p= 0.0012. Observou-se nos grupos experimentais com diabetes (G3 e G5), na bexiga urinária, o urotélio, o estroma e o músculo detrusor, sofrem alterações patológicas progressivas observadas pela microscopia eletrônica de transmissão. Conclusões: O diabetes eleva de forma significativa a pressão uretral durante a micção e o tempo de contração do detrusor após seis semanas. Após 20 semanas de indução do diabetes há hipocontratilidade do detrusor devido aos elevados níveis de pressão uretral que funciona como um fator obstrutivo ao esvaziamento vesical. As alterações ultra-estruturais observadas nas fibras musculares (miócitos) podem sugerir uma alteração metabólica e consequentemente disfunção do músculo detrusor. O citrato de sildenafil promoveu uma redução parcial da pressão uretral durante a micção em ratas diabéticas.

\title{
HIDROCEFALIA EXPERIMENTAL E NEUROPROTEÇÃO: EFEITOS DO CETOPROFENO NA HIDROCEFALIA INDUZIDA PELO CAULIM EM RATOS LACTENTES
}

\author{
Karinna Verissimo Meira \\ Orientadora: Profa. Dra. Luiza da Silva Lopes \\ Tese de Doutorado apresentada em 26/07/2010
}

A hidrocefalia é uma síndrome complexa, caracterizada pelo acúmulo de líquido cerebrospinal no interior dos ventrículos cerebrais. Considerando que a fisiopatologia da hidrocefalia é multifatorial e um dos mecanismos envolvidos na lesão ao tecido nervoso é a isquemia, e ainda que o cetoprofeno demonstrou possuir um efeito neuroprotetor no infarto cerebral, este trabalho visa estudar o possível efeito neuroprotetor do cetoprofeno na hidrocefalia experimental. Foram utilizados 56 ratos da linhagem Wistar, com 7 dias de idade, os filhotes foram submetidos à indução da hidrocefalia pelo método da injeção intracisternal de caulim a 20\%. Cetoprofeno foi administrado intraperitonialmente por 3 ou 14 dias consecutivos a partir da indução da Hidrocefalia. Aferição do peso corporal diário e testes comportamentais foram realizados. Sete, 14 ou 21 dias após a indução da Hidrocefalia os animai foram sacrificados, através de perfusão transcardíaca com solução salina sobre anestesia profunda e seus encéfalos foram removidos , fixado com paraformaldeído $3 \%$ em tampão fosfato $0,1 \mathrm{M}$ e processados para inclusão em parafina. Preparações histológicas foram então realizadas para a análise por coloração hematoxilina eosina, solocromo-cianina e imunoistoquímica para o GFAP. As diferentes metodologia de avaliações demonstraram que os animais hidrocefálicos apresentavam um redução do ganho ponderal do primeiro ao décimo segundo dia ápos a indução pelo caulim e este intervalo foi reduzido para cinco dias a partir do primeiro dia de indução somente nos grupo experimental que recebeu o tratamento por 14 dias com cetoprofeno. Nesse grupo a avaliação imunohistoquímica para GFAP, demonstrou ainda uma redução dos astrócitos reativos no corpo caloso, quando comparado com os hidrocefálicos não tratados. Apesar desses resultados positivos estudos adicionais são imperativos antes da sugestão do uso clínico deste antinflamatório como adjuvante no tratamento da Hidrocefalia.

\section{INFLUÊNCIA DA ALTURA E DO TIPO DE SALTO DE SAPATO NO RETORNO VENOSO DA MULHER JOVEM AVALIADA POR PLETISMOGRAFIA A AR}

\author{
Wagner Tedeschi Filho \\ Orientador: Prof. Dr. Carlos Eli Picinato \\ Dissertação de Mestrado apresentada em 29/07/2010
}

A influência do salto de sapatos na função venosa é controversa e pouco abordada na literatura. A importância da ergonomia na qualidade de vida é um fator consagrado e situações que a prejudiquem como permanência prolongada na posição supina, qualidade dos calçados e condições do local de trabalho podem interferir na saúde do indivíduo. Objetivo: 
O objetivo foi estudar a influência da altura do salto do sapato feminino na drenagem venosa dos membros inferiores, através da pletismografia a ar (PGA) utilizando seus parâmetros clássicos Índice de Enchimento venoso (IEV), Fração de Ejeção (FE) e Fração de Volume Residual (FVR) assim com estabelecer correlação entre os achados objetivos do estudo pletismográfico com a percepção das usuárias a respeito dos diferentes tipos de calçados quando utilizados por diferentes períodos de tempo. Método: Trinta mulheres, com idade média de 26,4 anos, assintomáticas, utilizando calçados de tamanhos apropriados, foram examinadas em 4 momentos: descalças $(0 \mathrm{~cm})$, salto médio agulha $(3,5 \mathrm{~cm})$, salto alto agulha $(7 \mathrm{~cm})$ e salto plataforma $(7 \mathrm{~cm})$. Apresentavam índice de massa corporal $<25$ e foram classificadas de acordo com a Classificação Internacional CEAP, em critérios: clínico (C0 ou C1), etiológico (Ep), anatômico (As) e fisiopatológico (Pr). Os valores de IEV, FE e FVR foram separados em quatro categorias para cada situação diferente de salto e comparadas entre si, utilizando-se a análise de variância para médias repetidas (ANOVA). A percepção de conforto, peso, dor e edema das mulheres frente aos diferentes tipos e alturas de saltos foram avaliados através de um questionário auto-aplicável respondido por 50 voluntárias. Resultados: Houve aumento significativo da FVR nos grupos de salto de 7,0 cm tanto agulha quanto plataforma (sendo o último com valores ainda maiores de FVR) quando comparados com o grupo descalço $(\mathrm{p}<0,05)$. O FVR no grupo de salto baixo $(3,5 \mathrm{~cm})$ apresenta valores significativamente mais altos quando comparado ao grupo descalço $(\mathrm{p}<0,05)$, porém não houve diferença em relação aos outros grupos de saltos mais altos apesar da forte tendência de aumento neste últimos. O FE apresentou queda significativa nos grupos de saltos mais altos de $7 \mathrm{~cm}$ (agulha e plataforma) em relação ao grupo descalço $(p<0,05)$. O IEV comportou-se de maneira semelhante nas três situações avaliadas. A correlação de Pearson evidencia a correlação inversa entre FE e FVR de forma que saltos de $7 \mathrm{~cm}$ ocasionam pior desempenho sistólico e diastólico com menores valores da FE e maiores valores de FVR, respectivamente. A análise dos questionários deixa evidente $(\mathrm{p}<0,001)$ a correlação das queixas venosas mais frequentes com o uso de saltos mais altos, assim como também com períodos mais prolongados de uso dos mesmos. Conclusão: $\mathrm{O}$ salto alto diminui a função de bomba muscular demonstrado pela queda da FE e aumento da FVR, podendo, com o seu uso contínuo, provocar hipertensão venosa nos membros inferiores, sendo preditivo de sintomatologia na doença venosa segundo a avaliação das próprias usuárias de saltos altos.

\title{
ESTUDO DA REATIVIDADE VASCULAR E ANÁLISE DO EFEITO DO CILOSTAZOL NA ISQUEMIA/REPERFUSÃO EM ARTÉRIA FEMORAL DE COELHO
}

\author{
Mariana Raphaela Garcia de Araujo \\ Orientador: Prof. Dr. Edwaldo Edner Joviliano \\ Dissertação de Mestrado apresentada em 30/07/2010
}

A importância clínica da isquemia/reperfusão nas extremidades exige a busca contínua de novas alternativas terapêuticas. O efeito protetor do cilostazol, na isquemia aguda tem sido demonstrado em diferentes territórios. O cilostazol é um inibidor da PDE 3A., o que leva a um aumento de AMPc.Foi proposto avaliar a reatividade vascular através de anéis de artéria femoral de coelhos machos com curvas dose-resposta com drogas vasodilatadoras dependentes de endotélio (Ach e A23) e independentes de endotélio (NPS), em condições de isquemia/reperfusão, com e sem o cilostazol. Foram dosados os metabólitos do NO no sangue e musculatura esquelética além de marcador de lesão muscular , creatinofosfoquinase (CK). Inicialmente foi definido o modelo experimental com a pré-tensão ideal e tempos de isquemia e reperfusão que levariam a lesão endotelial. Após, foram iniciados os testes com cilostazol endovenoso em diferentes tempos. A pré-tensão ideal foi de 2 gramas $(\mathrm{p}<0,05)$ e o tempo em que ocorria lesão endotelial detectada foi de 120 minutos de isquemia e 90 minutos de reperfusão, sem repercussão na musculatura lisa do anel vascular.Como resultados constatou-se que não houve diferença estatística nos marcadores plasmáticos (NO plasma e CK plasmático) entre os grupos. Houve aumento do NO muscular ( $\mathrm{p}<0,01$ ) no grupo de 120 minutos de isquemia e 90 minutos de reperfusão. Os grupos em que houve apenas o fenômeno de isquemia/reperfusão e que o cilostazol foi administrado imediatamente antes da isquemia, não apresentaram diferença estatística, mas apresentaram menor relaxamento do que o grupo controle. $O$ grupo em que o cilostazol foi administrado no início do procedimento apresentou maior relaxamento em relação ao grupo I/R. Os marcadores plasmáticos de degradação do NO aumentaram quando o cilostazol foi associado ao fenômeno da isquemia/reperfusão independente do momento em que foi administrado. Não houve diferença estatística quando da isquemia/reperfusão ou apenas da administração do cilostazol. O marcador plasmático de lesão muscular (CPK) apresentou aumento apenas quando houve administração de cilostazol antes do fenômeno de isquemia/reperfusão. A partir dos resultados verifica-se que: 1) O cilostazol quando administrado previamente ao fenômeno de isquemia/reperfusão de extremidade tem um efeito protetor na reatividade vascular dependente do endotélio; 2) a associação do fenômeno de isquemia/reperfusão com o uso do cilostazol leva a maior produção dos metabólitos do NO. 


\title{
CAPACIDADE FUNCIONAL DE PACIENTES SUBMETIDOS A NEUROCIRURGIA ONCOLÓGICA
}

\author{
Marcela dos Reis Bigatão \\ Orientador: Profa. Dra. Marysia Mara Rodrigues do Prado de Carlo \\ Dissertação de Mestrado apresentada em 21/09/2010
}

Introdução: A capacidade funcional refere-se fundamentalmente à potencialidade humana para o desempenho ocupacional, imprescindível para uma melhor qualidade de vida. O objetivo desta pesquisa, aprovada pelo Comitê de Ética em Pesquisa do HCFMRP-USP (processo no 648/2008), foi avaliar a capacidade funcional de pacientes submetidos a neurocirurgia oncológica e sua relação com a qualidade de vida. Método: Durante o período de maio/08 a abril/09 (12 meses) foram avaliados 52 sujeitos adultos de ambos os sexos; o grupo experimental teve 26 pacientes, sendo 14 com diagnóstico de meningioma (grupo1) e 12 com diagnóstico de glioma de alto grau (grupo 2); e o grupo controle teve 26 sujeitos, subdivididos em grupos: $1 \mathrm{~A}$ (pareado com o grupo 1) e 2A (pareado com grupo 2). Foram realizados dois tipos de dinamometria - avaliação de força de preensão (Grip TrackTM Testing) e de pinça (Pinch TrackTM Testing) com equipamento computadorizado Tracker SystemTM; aplicação de protocolos internacionais validados no Brasil - Hospital Anxiety and Depression Scale - HAD, Item Short-Form Health Survey - SF-36 e Health Assessment Questionnaire - HAQ, no período préoperatório e no terceiro mês de pós-operatório. Na análise estatística foram aplicados os testes Mann-Whitney, Wilcoxon e Coeficiente de Correlação de Spearman Resultados: Constatou-se que nos três primeiros meses de pós operatório houve aumento da capacidade funcional dos sujeitos dos grupos experimentais (1 e 2) e diminuição dos sintomas de ansiedade e depressão; não houve diferença significativa nos testes de força no pré e no pós operatório, mas ambos os grupos apresentam diminuição de força no membro dominante em comparação com os grupos controle. Houve correlações de forte magnitude entre os dados coletados através dos testes Grip TrackTM Testing, Pinch TrackTM Testing; protocolos: HAD, HAQ e SF-36, com rho 0,600 a 0,969. Os domínios aspecto social e emocional do instrumento de qualidade de vida mostraram uma piora no pós-operatório imediato. Esses resultados corroboram a compreensão ampliada do conceito de funcionalidade, como proposto na "Classificação Internacional de Funcionalidade e Incapacidade e Saúde" (CIF). Conclusão: A funcionalidade está diretamente relacionada com a qualidade de vida, principalmente nos aspectos psicossociais, sendo necessária compreendê-la de forma mais ampla do que funções físicas específicas, para implementar planos de tratamentos mais adequados para os sujeitos com tumor cerebral, tanto no pré como no pós operatório, com acompanhamento de uma equipe multidisciplinar.

\section{Clínica Médica}

\section{CONTRIBUIÇÃO DA ATENÇÃO FARMACÊUTICA AO TRATAMENTO DE PACIENTES COM DOENÇAS INFLAMATÓRIAS INTESTINAIS}

\author{
Nathalie de Lourdes Sousa Dewulf \\ Orientador: Prof. Dr. Luiz Ernesto de Almeida Troncon \\ Tese de Doutorado apresentada em 21/07/2010
}

As doenças inflamatórias intestinais (DII) - doença de Crohn e retocolite ulcerativa, são condições crônicas que, na maioria dos casos, exigem controle com terapia medicamentosa. A atenção farmacêutica (AF), definida como a provisão responsável do tratamento farmacológico, com o propósito de alcançar resultados concretos que melhorem a qualidade de vida do paciente, constitui nova forma de cuidado ao paciente, que necessita ser mais extensivamente avaliada. Este estudo teve o objetivo de avaliar a contribuição da atenção farmacêutica ao tratamento clínico de pacientes com DII em acompanhamento ambulatorial em hospital terciário. Ao longo de um ano, foi avaliado um grupo que recebeu a atenção farmacêutica (GAF; N=18) e um grupo controle ( $\mathrm{GC} ; \mathrm{N}=17$ ) não submetido aos procedimentos da $\mathrm{AF}$. Os resultados da contribuição da AF foram avaliados pela comparação de diferentes variáveis entre os grupos, que foram obtidas na primeira entrevista - T(0), aos seis - T(6) e 12 - T(12) meses do estudo. Quanto aos aspectos clínicos, houve redução significativa dos índices de atividade clínica de T(6) para T(12) no GAF (mediana; variação: 2,20; 0,99 - 3,77 versus 1,90; $0,99$ - 3,77; $\mathrm{p}=0,02)$, o que não ocorreu no GC (1,69; 0,99 - 3,77 versus 1,$69 ; 0,99$ - 3,48). No GAF, houve aumento significativo do percentual de pacientes mais aderentes ao tratamento medicamentoso $(27,8 \%$ versus $72,2 \%$; p $<0,05)$, quando da avali- 
ação por meio do teste de Morisky, mas não foram observadas diferenças $(72,2 \%$ versus $88,9 \%$ ) na adesão avaliada pelo cotejo entre medicamentos utilizados e prescrições registradas. Em ambas as formas de avaliação da adesão, tanto pelo teste de Morisky (41,2\% versus 41,2\%), quanto pelo confronto das medicações utilizadas e prescrições registradas ( $88,2 \%$ versus $82,4 \%$ ), não foram observadas alterações no GC. Houve aumento significativo dos índices de conhecimento do paciente sobre o tratamento no GAF entre T(0) e T(12) (mediana; variação: 80\%; 40\% - 100\% versus 100\%; 100\% - 100\%; $\mathrm{p} \leq 0,0001)$, o que não ocorreu no GC $(80 \% ; 0$ - $100 \%$ versus $80 \% ; 60 \%-100 \%)$. No que se refere à qualidade de vida, avaliada pelo instrumento SF36, houve diferenças estatisticamente significativas nos dois grupos apenas no domínio de saúde mental. No GAF, houve elevação dos escores deste domínio entre $\mathrm{T}(0)$ e $\mathrm{T}(12)(54,0$ versus 66,$0 ; \mathrm{p}=0,04)$, o que, também ocorreu no $\mathrm{GC}(60,0$ versus 68,$0 ; \mathrm{p}=0,01)$. Porém, no GAF, esta mudança ocorreu mais precocemente, de $\mathrm{T}(0)$ para $\mathrm{T}(6)(54,0$ versus 66,$0 ; \mathrm{p}<0,01)$. AAF possibilitou a identificação, em média, de 3,8 problemas relacionados ao medicamento por paciente, que em sua maioria foram resolvidos, com intervenções predominantemente focadas em orientações aos pacientes. Os pacientes do GAF, ao término do estudo, apresentaram alto grau de satisfação com a AF. Os resultados obtidos permitem concluir que a introdução de um programa de atenção farmacêutica a pacientes ambulatoriais com DII seguidos em hospital terciário trouxe contribuição positiva, proporcionando benefícios mensuráveis aos pacientes.

\title{
Farmacologia
}

\section{INFLUÊNCIA DE VIAS INIBITÓRIAS E FACILITATÓRIAS DESCENDENTES DO NÚCLEO PRÉ-TECTAL ANTERIOR SOBRE A HIPERALGESIA MECÂNICA OU TÉRMICA, PRIMÁRIA E SECUNDÁRIA, CAUSADAS POR INFLAMAÇÃO PERIFÉRICA}

\author{
João Walter de Souza Silveira \\ Orientador: Prof. Dr. Wiliam Alves do Prado \\ Tese de Doutorado apresentada em 01/07/2010
}

A informação nociceptiva é modulada na periferia, no corno dorsal da medula espinal e em centros supraespinais. Diversos mecanismos estão envolvidos nesse processamento, incluindo inibição e facilitação exercidas por vias descendentes. Na vigência de processo inflamatório, núcleos supraespinais exibem plasticidade que geram mudanças dinâmicas na modulação descendente da nocicepção. Neste trabalho, utilizamos testes comportamentais e imunohistoquímica para avaliar a influência da ablação química ou ativação com glutamato ( $5 \mathrm{nmol}$ ou $50 \mathrm{nmol})$ ou DAMGO (156 pmol ou 311 pmol) do núcleo pré-tectal anterior (NPtA) na instalação e desenvolvimento da hiperalgesia mecânica ou térmica, primária (medida na pata ipsilateral) e secundária (medida na pata contralateral e na cauda), até duas semanas após a injeção intraplantar (i.pl.) de formalina. Nossos resultados comportamentais apontam que o NPtA exerce efeito antinociceptivo semelhante sobre as hiperalgesia primárias e secundarias, porém as vias descendentes responsáveis por tais efeitos agem de forma diferente sobre a atividade neuronal das lâminas do corno dorsal da medula espinal. As lâminas contralaterais (que recebem as aferências da pata contralateral) foram sempre facilitadas pelos tratamentos que foram efetivos mesmo quando o resultado final foi inibição da hiperalgesia secundária. Já a hiperalgesia primaria sofreu forte influencia inibitória descendente sobre a atividade neuronal das lâminas do corno dorsal ipsilateral que se correlacionou diretamente com os resultados comportamentais. Os resultados comportamentais também mostram que o NPtA parece exercer influencia semelhante sobre as hiperalgesias mecânica e térmica. Porém, a avaliação da atividade neuronal das lâminas do corno dorsal mostra que no inicio do processo inflamatório vias descendentes do NPtA inibem as lâminas profundas ipsilaterais em resposta a estimulação mecânica e, quando há estimulação térmica a inibição se dá nas lâminas ipsilaterais superficiais. Efeito oposto é observado com a microinjeção de 311 pmol de DAMGO no NPtA imediatamente após a injeção de formalina na pata, onde observa-se inibição das lâminas superficiais ipsilaterais em resposta a estimulação mecânica e inibição mais discreta das lâminas profundas ipsilaterais em resposta a estimulação térmica. A atividade neuronal da lâmina $\mathrm{V}$ do corno dorsal ipsilateral mostra forte correlação com a hiperalgesia primária mecânica e térmica desencadeada pela injeção de formalina na pata. Por outro lado, a hiperalgesia mecânica secundária observada na pata contralateral imediatamente após formalina i.pl. não encontrou correlação com a atividade neuronal do corno dorsal contralateral. Circuitos glutamatérgicos mais sensíveis presentes no NPtA e ativados por baixas doses de glutamato, desencadeiam facilitação descendente que aparece somente em condições fisiológicas, cuja função fisiopatológica precisa ser melhor estudada. 


\title{
CARACTERIZAÇÃO FARMACOLÓGICA DO EFEITO ANTINOCICEPTIVO INDUZIDO PELA EPIBATIDINA EM MODELO DE DOR NEUROPÁTICA EM RATOS
}

\author{
Karina Abdo Costa \\ Orientador: Prof. Dr. Wiliam Alves do Prado \\ Tese de Doutorado apresentada em 05/07/2010
}

Os receptores nicotínicos são encontrados no Sistema Nervoso Central e exercem papel na modulação sináptica, na plasticidade neuronal e em diversas funções cognitivas. A diversidade dos receptores nicotínicos associada ao seu possível envolvimento em diferentes processos fisiológicos e patológicos vem sendo amplamente estudado. Vários estudos demonstraram que a administração de agonistas nicotínicos por via sistêmica, intratecal ou intracerebroventricular causa antinocicepção, sendo que este efeito parece depender da ativação de centros supraespinais. O presente estudo examinou o efeito da injeção sistêmica, da microinjção no núcleo pretectal anterior (NPtA) e na substância cinzenta periaquedutal ventrolateral ( $\mathrm{SCPvl})$ da epibatidina, um agonista de receptores nicotínicos neuronais, sobre a alodínia mecânica induzida por ligadura dos troncos dos nervos espinais L5 e L6. Também se avaliou o efeito da microinjeção de atropina ou mecamilamina sobre o efeito antinociceptivo induzido pela microinjeção de epibatidina na SCPvl e o efeito da mecamilamina sobre o efeito antialodínico observado após injeção sistêmica da epibatidina. Inicialmente se observou que a ligadura dos troncos L5 e L6 dos nervos espinais induz alodínia mecânica já no $2^{\circ}$ dia após cirurgia, mantendo-se constante até pelo menos o $28^{\circ}$ dia após a ligadura. Nenhuma alteração no limiar de resposta a estímulos mecânicos foi observada nos animais "sham" ou na pata contralateral. A injeção sistêmica $(3,0 \mu \mathrm{g} / \mathrm{kg}$, i.p.) de epibatinida induz efeito antialodínico, porém essa mesma dose não altera o desempenho dos animais no teste do rota-rod. Além disso, a microinjeção na SCPvl, mas não no NPtA $(0,3 \mu \mathrm{g} / 0,3 \mu \mathrm{L})$ de epibatidina induziu efeito antialodínico. Mecamilamina microinjetada na SCPvl aboliu o efeito antinociceptivo induzido pela epibatidina microinjetada neste mesmo núcleo e o efeito da epibatidina administrada por via sistêmica. Estes resultados permitem concluir que a injeção sistêmica e central de epibatidina induz efeito antialodínico no modelo de dor neuropática e esse efeito depende da interação dessa substância com receptores nicotínicos localizados na SCPvl.

\section{MECANISMOS ENVOLVIDOS NAS RESPOSTAS CARDIOVASCULARES À MICROINJEÇÃO DE L- PROLINA NO TERCEIRO VENTRÍCULO DE RATOS NÃO ANESTESIADOS}

\author{
Silvana Lopes-Silva \\ Orientador: Prof. Dr. Fernando Morgan de Aguiar Corrêa \\ Dissertação de Mestrado apresentada em 09/08/2010
}

A L- Prolina (L- Pro) é um aminoácido não essencial, endógeno, considerado como possível neurotransmissor ou neuromodulador do SNC. O terceiro ventrículo (3 V) é uma cavidade do cérebro, parte do sistema ventricular cerebral, contigua ao hipotálamo, região na qual foi detectada a existência de sistemas de recaptação e liberação de L- Pro. O objetivo deste estudo foi verificar os efeitos cardiovasculares causados pela microinjeção de L- Pro no 3 V e identificar os possíveis mecanismos periféricos envolvidos nestas respostas. A L- Pro foi injetada em um volume de $0,5 \mu \mathrm{L}$ no $3 \mathrm{~V}$. A microinjeção de L- Pro no $3 \mathrm{~V}$ causou respostas pressora e bradicárdica, dose-dependente, quando aplicada em ratos não anestesiados. As respostas cardiovasculares desencadeadas pela microinjeção de L- Pro no $3 \mathrm{~V}$ foram bloqueadas pela pré-tratamento endovenoso com dTyr(CH2)5(Me)AVP, um antagonista vasopressinérgico, sugerindo o envolvimento da liberação sistêmica de vasopressina na mediação destas respostas. A resposta pressora à L- Pro no 3 V não foi bloqueada pelo pré-tratamento sistêmico com o bloqueador ganglionar pentolínio, excluindo a possibilidade de uma mediação simpática da resposta pressora. Entretanto, a resposta bradicárdica foi inibida pelo bloqueio ganglionar, sugerindo ser esta uma resposta reflexa, consequente ao aumento da pressão arterial. Esta é a primeira evidência de efeitos cardiovasculares da administração de L- Pro em estruturas suprabulbares, bem como dos possíveis mecanismos periféricos envolvidos na sua mediação. Em conclusão, os presentes resultados indicam que a microinjeção de L- Pro no 3 V causa respostas pressora e bradicárdica de maneira dose-dependente, e que esta é mediada por liberação sistêmica de vasopressina. 


\title{
ENVOLVIMENTO DAS REDES NEURAIS DO NÚCLEO DORSAL DA RAFE E DA NEUROTRANSMISSÃO SEROTONINÉRGICA NO LOCUS COERULEUS EM PROCESSOS ANTINOCICEPTIVOS INDUZIDOS POR REAÇÕES DE FUGA ORIENTADA CAUSADAS PELO BLOQUEIO DOS RECEPTORES GABAA DO HIPOTÁLAMO MEDIAL
}

\author{
Audrey Francisco \\ Orientador: Prof. Dr. Norberto Cysne Coimbra \\ Dissertação de Mestrado apresentada em 27/08/2010
}

As projeções serotoninérgicas do núcleo dorsal da rafe (NDR) para o locus coeruleus (LC) desempenham um importante papel na modulação da dor. Modelos de antinocicepção induzidos pelo medo têm sido amplamente utilizados para melhor compreendermos os processos de modulação da dor. Com efeito, o bloqueio dos receptores GABAérgicos no hipotálamo medial (HM) induz tanto respostas comportamentais quanto uma antinocicepção subsequente aos comportamentos defensivos. O objetivo do presente estudo foi investigar o envolvimento do sistema serotoninérgico do sistema endógeno de inibição de dor, no NDR e no LC, nos processos antinociceptivos elaborados pelo bloqueio dos receptores GABAA do hipotálamo medial. A microinjeção do antagonista de receptores GABAA, bicuculina (40ng/0,2 L) no HM, induziu comportamentos defensivos, elaborados concomitantemente com processos antinociceptivos. A administração de 5,7-di-hidroxitriptamina ( $1 \mathrm{~g} / 0,2 \mathrm{~L})$, uma neurotoxina específica para neurônios serotoninérgicos, no NDR diminuiu a frequência e duração dos comportamentos de alerta defensivo e de fuga. Além disso, reduziu a antinocicepção induzida pela administração de bicuculina 5 e 14 dias após a lesão. Grupos independentes de animais pré-tratados no LC com os antagonistas de receptores serotoninérgicos metisergida (não seletivo) e cetanserina (com maior afinidade pelos receptores 5-HT2A/2C), na concentração de $5 \mathrm{~g} / 0,2 \mathrm{~L}$, tiveram redução dos limiares nociceptivos que seguem os comportamentos de fuga elaborada, organizada pelo HM, sem alteração significativa nos comportamentos defensivos. Esses dados sugerem que neurônios serotoninérgicos do núcleo dorsal da rafe encontram-se diretamente envolvidos na organização das respostas de fuga elaborada, bem como na subsequente antinocicepção induzida pelo medo inato. Os presentes achados sugerem, ainda, que os neurônios serotoninérgicos do NDR que se projetam para o LC, modulam apenas a antinocicepção induzida pelo medo e pelo pânico, sem alteração na organização de comportamentos induzidos pelo bloqueio de receptores GABAA no HM.

\section{EFEITO DO TAK-778 NA INTERAÇÃO OSTEOBLASTO-OSTEOCLASTO}

\author{
Larissa Sverzut Bellesini \\ Orientador: Prof. Dr. Adalberto Luiz Rosa \\ Tese de Doutorado apresentada em 1\%09/2010
}

O objetivo do presente estudo foi investigar o efeito do TAK-778 na interação osteoblasto-osteoclasto e seu efeito em osteoclastos. O efeito do TAK-778 na interação osteoblasto-osteoclasto foi avaliado por meio da análise da expressão de moléculas envolvidas no controle da osteoclastogênese, expressas por osteoblastos, e por meio das avaliações da formação e da atividade de osteoclastos expostos ao meio condicionado por osteoblastos. O efeito do TAK-778 em osteoclastos foi avaliado por meio das análises da formação e atividade osteoclásticas. Osteoblastos diferenciados a partir de células de medula óssea humana foram subcultivados na presença de meio osteogênico suplementado com TAK778 (10-5M) ou veículo. Aos 7 dias de cultivo, a expressão dos fatores interleucina 1 alfa (IL1A), interleucina 1 beta (IL1B), interleucina 6 (IL6), interleucina 11 (IL11), fator de necrose tumoral alfa (TNFA), ligante do receptor ativador do fator nuclear-Kappa B (RANKL), osteoprotegerina (OPG) e molécula de adesão intercelular 1 (ICAM1) foi avaliada por meio de PCR em tempo real, utilizando o sistema Taqman. Por meio de ensaios imunoenzimáticos (ELISA), com exceção da ICAM1 e RANKL, a expressão destes fatores bem como de prostaglandina E2 (PGE2) também foi avaliada. Em adição, células mononucleares isoladas a partir de medula óssea humana foram diferenciadas em osteoclastos que foram cultivados em meio de cultura suplementado com meio condicionado por osteoblastos cultivados na presença de TAK-778 (10-5M) ou veículo, para avaliação do efeito do TAK-778 na interação osteoblasto-osteoclasto. O efeito do TAK-778 sobre osteoclastos foi avaliado por suplementar o meio osteoclastogênico com TAK-778 (10-7M) ou veículo. A formação e atividade osteoclásticas foram avaliadas, respectivamente, por meio da marcação histoquímica para TRAP e de ensaios de reabsorção de fosfato de cálcio. Os resultados obtidos indicaram que, em osteoblastos, o TAK-778 estimula a expressão de RANKL, OPG, ICAM1 e PGE2, inibe a expressão de IL6 e não altera a expressão de IL1B, IL11 e TNFA. Em adição, a 
expressão de IL1A não foi detectada nos grupos de células cultivados na presença ou ausência de TAK-778. O meio condicionado por osteoblastos cultivados na presença de TAK-778 inibe a formação de osteoclastos, sem alterar a atividade de reabsorção destas células. Entretanto, o TAK-778 não exerceu efeito direto sobre a formação e atividade osteoclásticas. Estes resultados sugerem que a reduzida expressão de IL6 e a expressão aumentada de PGE2 por osteoblastos expostos ao TAK-778 tenham sido os responsáveis pela inibição da formação osteoclástica in vitro. Em modelos in vivo ou em sistemas de co-culturas, o TAK-778 poderia exercer um efeito diferente sobre a osteoclastogênese, por estimular a expressão de RANKL, ICAM1 e OPG em osteoblastos.

\title{
EFEITOS DO TEMPOL SOBRE ALTERAÇÕES HEMODINÂMICAS ASSOCIADAS À EMBOLIA PULMONAR AGUDA EM CARNEIROS
}

\author{
Ozélia Sousa Santos \\ Orientador: Prof. Dr. José Eduardo Tanus dos Santos \\ Dissertação de Mestrado apresentada em 13/09/2010
}

Embolia pulmonar aguda (EPA) é uma importante causa de morbidade e mortalidade a nível mundial. Há evidências que o estresse oxidativo está aumentado em condições de hipertensão arterial pulmonar, inclusive durante a EPA. Contudo, a importância do aumento do estresse oxidativo nas alterações hemodinâmicas após a EPA não está bem elucidada. O tempol é conhecido como um sequestrador de radicais livres e mimético da superóxido dismutase. Neste estudo nós examinamos se o tempol atenua as mudanças hemodinâmicas associadas à EPA. Os animais do grupo Sham (n=4) receberam apenas infusão de salina, no grupo $\operatorname{EPA}(n=8)$ receberam infusão de salina como pré-tratamento seguido de infusão de coágulos autólogos, os animais do grupo tempol+EPA (n=7) receberam pré-tratamento com tempol (1 mg/Kg/min) seguido de indução da EPA, no grupo EPA+tempol $(n=8)$ receberam infusão de coágulo seguido de tratamento com tempol. Foram realizadas medidas da atividade das MMPs em amostras de ventrículo direito. A determinação de espécies reativas de oxigênio no ventrículo direto foi avaliado pelo método de DHE e a liberação de TnIc por imunoensaio enzimático. Nenhuma diferença significativa foi encontrada no grupo Sham. A indução da EPA aumentou a pressão média da artéria pulmonar (de $15 \pm 2$ para $37 \pm 6 \mathrm{mmHg}$ ), o índice de resistência vascular pulmonar (de $211 \pm 71$ para $558 \pm 153 \mathrm{dina} . \mathrm{s} . \mathrm{cm}-5 . \mathrm{m}-2)$ e a dP/dt máx. (de $605 \pm 112$ para $1143 \pm 309 \mathrm{mmHg} / \mathrm{s}$ ) no grupo EPA (todos $\mathrm{P}<0,05$ ). A infusão do tempol trinta minutos antes da indução da EPA atenuou a pressão média da artéria pulmonar para $26 \pm 2 \mathrm{mmHg}$ e a dP/dt máx. para $737 \pm 53 \mathrm{mmHg} / \mathrm{s}$, (todos P <0,05). Quando infundido trinta minutos após a indução da EPA, tempol produziu atenuação similar da hipertensão pulmonar induzida pela EPA. A atividade gelatinolítica das MMPs foi aumentada no grupo EPA. O pré-tratamento e tratamento com tempol atenuou os aumentos tanto na atividade das MMPs, bem como o aumento nas concentrações de espécies reativas de oxigênio no ventrículo direito (ambos $\mathrm{P}<0,05)$. A EPA aumentou a concentração sérica de troponina I cardíaca, enquanto tais aumentos não foram achados nos animais pré-tratados ou tratados com tempol. Estes resultados sugerem que o uso de tempol antes e após a embolia pulmonar aguda protege o miocárdio possivelmente por reduzir o estresse oxidativo e reduzir a degradação de proteínas contráteis no coração pelas MMPs, portanto resultando em efeitos hemodinâmicos benéficos.

\section{Fisiologia}

\section{ORGANIZAÇÃO DAS CONEXÕES AFERENTES ÀS PORÇÕES MEDIAL E LATERAL DAS CAMADAS INTERMEDIÁRIAS E PROFUNDAS DO COLÍCULO SUPERIOR}

\author{
Plinio das Neves Favaro \\ Orientador: Profa. Dra. Eliane Comoli \\ Dissertação de Mestrado apresentada em 28/07/2010
}

O colículo superior (SC) é uma estrutura mesencefálica conhecida por ser responsável pela detecção e orientação da cabeça e olhos em direção a estímulos visuais (Grantyn, 1988; Sparks, 1999). Em roedores, uma distinção funcional é 
sugerida entre as regiões medial e lateral de SC. Especificamente, a porção medial do colículo superior parece envolvida na elaboração de comportamentos de aversão e fuga, enquanto a região lateral está relacionada a movimentos de orientação e aproximação, tal como observado na resposta predatória. Interessantemente, um aumento na imunorreatividade à proteína Fos foi encontrado na região medial do SC (SCm) após exposição do rato ao predador natural (Comoli e Cedraz-Mercez, 2009; Cedraz- Mercez e Comoli, 2009 ). Por outro lado, houve particular aumento na imunorreatividade à proteína Fos na porção lateral do SC (SCl) durante a caça predatória de baratas (Comoli e Canteras, 2000; Furigo et al., 2010). No presente trabalho foi realizado um estudo sistemático das conexões aferentes das porções mediais e lateral das camadas intermediárias do colículo superior com o uso do traçador retrógrado fluorogold, e alguns controles anterógrados com o traçador biotin-dextran (BDA). Todos os animais foram perfundidos 12-13 dias após a injeção do traçador, e então os cérebros foram detectados para FG ou BDA. Nosso resultados mostram que o $\mathrm{SCm}$ recebe projeções de áreas encefálicas envolvidas na organização das respostas defensivas como o circuito de defesa na zona medial do hipotálamo, o núcleo precommissural e a coluna dorsolateral da substância cinzenta periaquedutal. O SCm também recebe estímulos visuais corticais, do núcleo geniculado lateral e da região prétectal; aferências de regiões somatossensoriais isocorticais; aferências de áreas auditivas do isocórtex e do núcleo do lemnisco lateral; informações nociceptivas e informações de sistemas motores e associativos. Por outro lado, $\mathrm{o} \mathrm{SCl}$ recebe informações somatossensoriais relacionadas às vibrissas provenientes do complexo trigeminal, da porção ventral da zona incerta e da área de representação das vibrissas no córtex somatossensorial primário, bem como informações somatossensoriais provenientes da região de representação do nariz, boca e membros superiores no córtex somatossensorial primário. O SCl também recebe informações gustativas do núcleo parabraquial e do córtex gustativo; informações de sistemas motores e do núcleo da comissura posterior. Os resultados sugerem que o SCm integra principalmente informações visuais, auditivas, somatossensoriais e motivacionais relacionadas com a organização das respostas defensivas, enquanto o SCl integra informações somatossensoriais, gustativas, viscerais e motoras fundamentais para a resposta predatória.

\title{
MODULAÇÃO DO SISTEMA NITRÉRGICO CENTRAL NA EXPRESSÃO HIPOTALÂMICA E NA CONCENTRAÇÃO PLASMÁTICA DE VASOPRESSINA E OCITOCINA INDUZIDAS POR ALTERAÇÕ̃S DE VOLUME E OSMOLALIDADE DO LÍQUIDO EXTRACELULAR
}

\author{
Wagner Luis Reis \\ Orientador: Prof. Dr. José Antunes-Rodrigues \\ Tese de Doutorado apresentada em 06/08/2010
}

Dados deste laboratório demonstraram que a administração prévia intracerebroventricular (icv) de doadores de óxido nítrico (NO) induziram reduções nas concentrações plasmáticas de vasopressina (AVP) e ocitocina (OT) de ratos submetidos à estimulação central com salina hipertônica ou angiotensina-II (ANG-II), sugerindo o envolvimento do NO na liberação destes hormônios em resposta às variações de volume e osmolalidade do líquido extracelular. Este trabalho avaliou a participação do sistema nitrérgico central na expressão hipotalâmica da AVP e OT dos núcleos paraventricular (PVN) e supra-óptico (SON), comparando-as com suas concentrações plasmáticas em resposta à estimulação extracelular hipo ou hipervolêmica ou à estimulação central com ANG-II. Além disso, foi avaliado no PVN e SON os efeitos da privação hídrica sobre a expressão das enzimas sintase de NO neuronal (NOSn) e da heme oxigenase tipo 1 (HO-1), formadora de monóxido de carbono (CO). Para tanto, ratos Wistar $( \pm 280 \mathrm{~g})$ receberam via icv um inibidor da NOS (L-NAME, 250 $\mu \mathrm{g})$ ou um doador exógeno de NO (SNAP, $5 \mu \mathrm{g}$ ), sendo submetidos em seguida à hipovolemia provocada por uma hemorragia (HEM, $1 \mathrm{ml} / 100 \mathrm{~g}$ ) ou à hipervolemia induzida pela expansão isotônica (ISO, $\mathrm{NaCl} 0,15 \mathrm{M}$ ) ou hipertônica (HIPER, $\mathrm{NaCl} 0,30 \mathrm{M}$ ) de volume do líquido extracelular (EVEC, $2 \mathrm{ml} / 100 \mathrm{~g}$ ). Tanto a hemorragia quanto a estimulação angiotensinérgica promoveram aumentos da expressão do RNAm e da ativação neuronal da AVP, OT e NOSn nos núcleos PVN e SON, sendo observadas elevações nas concentrações plasmáticas de AVP e OT após a HEM e redução do conteúdo neurohipofiário de AVP e OT após injeção central de ANGII. O tratamento com L-NAME reduziu a expressão hipotalâmica do gene da NOSn nos animais submetidos à HEM ou à ANG-II e também potencializou as concentrações plasmáticas e a ativação de neurônios ocitocinérgicos no PVN e no SON após estímulo com ANG-II. Por outro lado, a injeção icv de SNAP reduziu a expressão do RNAm, a ativação neuronal e também a concentração plasmática de AVP e OT de ratos submetidos à hipovolemia sanguínea ou à ANG-II. Foi observado que, em resposta à expansão ISO ou HIPER, a concentração plasmática de OT e a expressão de RNAm da OT e NOSn no PVN e SON foram aumentadas, porém, somente a EVEC HIPER foi capaz de elevar a 10 concentração plasmática, a expressão do RNAm e a ativação de neurônios vasopressinérgicos. Além do mais, a inibição da NOS reduziu a expressão hipotalâmica do gene da NOSn e potencializou a resposta plasmática e a ativação 
neuronal para a OT e AVP em resposta à expansão ISO e HIPER. Entretanto, a expressão do RNAm e da concentração plasmática de AVPe OT induzida pelas EVEC ISO e HIPER foram reduzidas pela administração exógena de doador de NO. Foi observado ainda que a privação hídrica aumentou a formação de NO nos núcleos PVN e SON juntamente com o aumento da imunomarcação e da colocalização de HO-1 e NOSn. Desta maneira, o aumento da expressão gênica e da ativação hipotalâmica da NOSn durante as alterações de volume e/ou osmolalidade demonstram a importância fisiológica do NO na modulação da secreção de AVP e OT e, sob estas condições, o CO parece interagir com o sistema nitrérgico. A inibição da NOS reduz a expressão hipotalâmica da NOSn elevando a concentração plasmática de AVP e OT, enquanto que o doador de NO diminui a expressão gênica e a ativação neuronal da AVP e da OT no núcleos PVN e SON. Desta forma, os dados sugerem que o NO formado, sob condições de hiperosmolalidade e hipo ou hipervolemia, pode ser um regulador inibitório da síntese e secreção de hormônios neurohipofisários, impedindo uma produção e liberação acima da necessária de AVP e OT para restabelecer a homeostase hidroeletrolítica.

\title{
CONTROLE NEUROENDÓCRINO DA INGESTÃO ALIMENTAR DURANTE A TOLERÂNCIA A ENDOTOXINA
}

\author{
Beatriz de Carvalho Borges \\ Orientador: Profa Dra Lucila Leico Kagohara Elias \\ Tese de Doutorado apresentada em 10/08/2010
}

A exposição aguda ao lipopolissacarideo (LPS) de bactéria e um potente indutor de resposta imunologica, bem como de hipofagia. Entretanto, durante exposição prolongada a endotoxina ocorre uma dessensibilização das respostas ao LPS. Por meio de injeções repetidas de LPS (6 LPS) $(100 \mu \mathrm{g} / \mathrm{kg}$, intraperitoneal), induzimos tolerância a endotoxina, em comparação com o tratamento com uma única injeção (1 LPS). O grupo 1 LPS, mas não o grupo 6 LPS, apresentou redução da ingestão de alimento e do peso corporal. O efeito anorexigenico do LPS esteve associado com concentrações elevadas de leptina circulante, expressão aumentada do RNAm do OB-Rb e MC4R, aumento do numero de neurônios que expressam p-STAT-3, concentração reduzida de 2- araquidonoilglicerol (2-AG), bem como atividade reduzida da proteína quinase ativada por AMP (AMPK) no hipotálamo. Por outro lado, a hipofagia observada apos estimulo com LPS não parece estar relacionada com alterações na expressão do gene da POMC no núcleo arqueado. A dessensibilização da hipofagia no grupo 6 LPS esteve relacionada com concentração elevada de 2-AG, ausência de fosforização da STAT-3 e aumento da fosforização da AMPK no hipotálamo. Ao avaliar a sensibilidade a leptina nos animais tratados com dose única ou doses repetidas de LPS, observamos que, nos ratos controles, a leptina reduziu a ingestão de alimento, o peso corporal, o conteúdo de 2-AG e a atividade da AMPK, e aumentou a expressão de p-STAT-3 no hipotálamo. No grupo 1 LPS a leptina não promoveu redução adicional na ingestão de alimento, na concentração de 2-AG e na atividade da AMPK, e também não aumentou ainda mais a fosforização da STAT-3. Curiosamente, em resposta a exposição repetida a endotoxina, observamos uma incapacidade da leptina em ativar a STAT-3, em inibir a fosforização da AMPK e em reduzir a concentração de 2-AG no hipotálamo, sugerindo que os animais tolerantes ao LPS apresentam resistência a leptina. Esta resistência a leptina durante a tolerância a endotoxina parece não estar relacionada com o aumento da expressão de SOCS-3. O presente modelo de inflamação prolongada pode contribuir para futuras investigações dos mecanismos de resistência a leptina.

\section{PAPEL DOS BARORRECEPTORES NA REGULAÇÃO NEURAL DA PRESSÃO ARTERIAL EM CAMUNDONGOS}

\section{Fernanda Luciano Rodrigues}

Orientador: Prof. Dr. Rubens Fazan Junior

Tese de Doutorado apresentada em 11/08/2010

O presente estudo avaliou o papel dos barorreceptores arteriais (aórticos e carotídeos) na regulação da pressão arterial (PA) e intervalo de pulso (IP) em camundongos acordados. Cinco dias antes dos experimentos, camundongos C57Bl foram submetidos à desnervação sino-aórtica (DSA) ou desnervação seletiva dos barorreceptores do arco aórtico (Ao-X) ou seio carotídeo (Ca-X), e receberam cânulas na artéria femoral e veia jugular. Após registro basal da PA, os camundongos receberam fenilefrina e bloqueadores de receptores autonômicos (metil atropina ou propranolol), para avaliação do tono autonômico cardíaco. A variabilidade da PA e do IP foram avaliadas no domínio do tempo, por cálculos 
estatísticos, e da frequência, por análise espectral (FFT), com espectros quantificados nas bandas de LF $(0,25-1,0 \mathrm{~Hz})$ e HF (1,0-5,0 Hz). O barorreflexo espontâneo foi avaliado por meio da técnica da sequência. A PA e sua variabilidade total foram maiores nos animais submetidos à DSA, Ao-X ou Ca-X. O IP não diferiu entre os grupos, porém sua variabilidade total foi menor após a DSA. Atropina não alterou o IP dos camundongos desnervados (total ou parcialmente), mas causou taquicardia nos intactos. A bradicardia após propranolol foi maior nos animais submetidos à DSA, Ao-X ou Ca-X. O aumento na variabilidade total da PA foi acompanhado de um significante aumento no LF e HF dos espectros da PA sistólica dos camundongos submetidos à DSA, Ao-X e Ca-X. Por outro lado, o LF e o HF da variabilidade do IP foram reduzidos após a DSA, Ao-X ou Ca-X, embora essa queda tenha sido menor nos camundongos submetidos à desnervação parcial (Ao-X ou Ca-X). O número de sequências barorreflexas não foi alterado pela DSA, embora o ganho destas sequências tenha sido reduzido após a remoção das aferências barorreceptoras. $\mathrm{O}$ duplo bloqueio de receptores autonômicos reduziu drasticamente o número de sequências PA/IP, tanto nos camundongos intactos como nos submetidos à DSA. Os resultados demonstraram que a presença de ambos os conjuntos de barorreceptores é necessária para manter a PA em níveis normais. Além disso, ambos os conjuntos de barorreceptores parecem ser igualmente importantes na regulação do tono autonômico cardíaco em camundongos. A análise espectral demonstrou um importante papel dos barorreceptores arteriais nas oscilações de LF do IP. O número de sequências PA/IP antes e após o duplo bloqueio autonômico sugere que 5 dias após a DSA, os camundongos ainda apresentam variações no IP, que são dirigidas pela PA e mediadas pelo sistema nervoso autônomo.

\title{
MECANISMOS BULBO-PONTINOS ENVOLVIDOS NO ACOPLAMENTO SIMPÁTICO E RESPIRATÓRIO EM SITUAÇÕES DE NORMÓXIA E HIPÓXIA EM RATOS
}

\author{
João Henrique da Costa Silva \\ Orientador: Prof. Dr. Benedito H. Machado \\ Tese de Doutorado apresentada em 12/08/2010
}

No presente estudo avaliamos a participação da neurotransmissão glutamatérgica em diferentes sub-regiões do NTS e também das conexões bulbo-pontinas na manutenção dos parâmetros autonômicos e ventilatórios basais e em resposta à ativação do quimiorreflexo em ratos. Avaliamos também a participação dos mecanismos glutamatérgicos no NTS de ratos jovens submetidos previamente à hipóxia crônica intermitente por dez dias ( $\mathrm{HCI} ; 6 \%$ de $\mathrm{O} 2$ por aproximadamente 40 seg, a cada 9 min, durante 8 horas por dia) no controle dos parâmetros autonômicos e ventilatórios basais e das respostas à ativação do quimiorreflexo. Os nossos experimentos foram realizados na preparação coração-tronco cerebral isolados, na qual foram registradas a frequência cardíaca e as atividades dos nervos frênico, vago cervical e simpático torácico. Os resultados mostraram que a microinjeção do ácido quinurênico (Kyn, antagonista dos receptores ionotrópicos do L-glutamato) no NTS intermediário (NTSi) e no NTS caudal anterior (NTSca) reduziu a atividade pós-inspiratória, aumentou a duração da inspiração e alterou o acoplamento simpático-respiratório durante a ativação do quimiorreflexo, levando a uma simpato-excitação relacionada a inspiração. Além disso, observamos que transecção das conexões bulbopontinas aboliu a atividade pós-inspiratória, aumentou a duração da inspiração e alterou o acoplamento simpático-respiratório durante a ativação do quimiorreflexo, com atenuação da simpato-excitação. Nos estudos realizados em ratos submetidos à HCI, observamos aumento no número de receptores glutamatérgicos (NMDA e AMPA) no NTSca, mas não no NTSi. O conjunto dos resultados indica que: i) a neurotransmissão glutamatérgica no NTS assim como as conexões bulbo-pontinas são importantes para a geração da atividade pós-inspiratória, para o controle da duração da inspiração e para a simpato-excitação relacionada com a expiração durante a ativação do quimiorreflexo; e ii) os animais submetidos à HCI apresentam alterações nos receptores glutamatérgicos no NTSca, as quais devem contribuir para as alterações no processamento das atividades respiratórias e simpáticas observadas nesse modelo experimental.

\section{ATIVIDADE PRÓ-PIRÉTICA DA VIA DO ÓXIDO NÍTRICO NO LOCUS COERULEUS}

\author{
Renato Nery Soriano \\ Orientador: Prof. Dr. Luiz Guilherme S. Branco \\ Tese de Doutorado apresentada em 16/08/2010
}

O óxido nítrico (NO) modula a resposta febril induzida por lipopolissacarídeo (LPS) no sistema nervoso central. Sabendo que os neurônios do locus coeruleus (LC) expressam as enzimas óxido nítrico sintase (NOS) e guanilato ciclase 
solúvel (sGC), no presente estudo avaliamos in vivo e ex vivo o possível papel da via NO-GMP cíclico (cGMP) no LC na febre induzida por injeção intraperitoneal (ip) de LPS. A temperatura corporal (Tb) de ratos foi registrada antes e depois de modulação da referida via no LC; e, além disso, foi medida a concentração de nitrito/nitrato (NOx) e cGMP no núcleo. Ratos não-anestesiados e não-confinados receberam uma microinjeção no LC de um inibidor não-seletivo da NOS (L-NMMA), ou de um doador de NO (NOC12), ou de um inibidor da sGC (ODQ), ou de um análogo do cGMP (8-Br-cGMP), e receberam também uma injeção i.p. de LPS. A inibição da NOS ou da sGC antes da injeção de LPS prolongou significativamente a latência para o início da resposta febril. Durante o curso da febre, a inibição destas enzimas atenuou a resposta febril, enquanto que o NOC 12 e o 8-BrcGMP exacerbaram tal resposta. Os resultados indicam, pois, que a via NO-cGMP no LC exerce um papel pró-pirético. Além disto, observamos um aumento expressivo nas concentrações de NOx e cGMP no LC duas horas e meia após a injeção i.p. de LPS, indicando que a resposta febril é acompanhada por estimulação da via NOcGMP no LC.

\title{
EFEITO DA MICROINJEÇÃO DE AMINOÁCIDOS EXCITATÓRIOS NO CÓRTEX CINGULADO ANTERIOR E AVALIAÇÃO DAS SUAS CONEXÕES COM A SUBSTÂNCIA CINZENTA PERIAQUEDUTAL SOBRE A MODULAÇÃO DA IMOBILIDADE TÔNICA E DA NOCICEPÇÃO EM COBAIAS
}

\author{
Márcio Ramos Coutinho \\ Orientador: Profa. Dra. Leda Menescal de Oliveira \\ Tese de Doutorado apresentada em 26/08/2010
}

A imobilidade tônica (IT) é uma resposta defensiva inata, caracterizada pelo estado profundo e temporário de acinesia, evocada por meio de manobras de restrição física e inversão da postura do animal. Nossos estudos prévios demonstraram que a estimulação glutamatérgica da porção dorsomedial/dorsolateral da substância cinzenta periaquedutal (SCPd) diminui a duração da resposta de IT em cobaias (Cavia porcellus). Algumas evidências sugerem que o córtex cingulado anterior (CCA) constitui em uma importante fonte glutamatérgica para a SCPd. Além disso, sabe-se que o CCA exerce destacada função no processamento de respostas envolvidas em contextos motivacionais defensivos e de nocicepção em humanos e em ratos. Assim, o presente trabalho teve como objetivo avaliar o efeito da microinjeção de DLH (agonista glutamatérgico) no CCA de cobaias sobre a duração dos episódios de IT e sobre a nocicepção, analisada pelo teste de vocalização induzida pela aplicação de um estímulo nocivo agudo periférico e pelo teste nociceptivo de retirada da pata.

Esses testes nociceptivos permitiram analisar separadamente o componente afetivomotivacional e sensóriodiscriminativo da dor, respectivamente. O presente trabalho teve o objetivo também de avaliar o efeito do bloqueio funcional da SCPd, previamente a microinjeção de DLH no CCA, sobre a duração dos episódios de IT e sobre a resposta afetivomotivacional de dor. Por fim, o presente estudo se propôs investigar, por meio da microinjeção de neurotraçador (Texas red conjugado a dextrana de amina biotinizada), possíveis conexões que partem do CCA e se dirigem diretamente para a SCPd em cobaias. Os presentes resultados demonstraram que as microinjeções de DLH (30 nmol / 0,2 $\mu$ l) diminuíram a duração da resposta de IT. Este efeito foi bloqueado pela prévia administração de 3,6 nmol de MK-801 (antagonista dos receptores glutamatérgicos do tipo NMDA) no CCA ou na SCPd. Os resultados do presente estudo também mostraram que a microinjeção de DLH (30 nmol / 0,2 $\mu \mathrm{l})$ no CCA produziu aumento da resposta de vocalização induzida pela aplicação de um estímulo nociceptivo, mas não sobre o reflexo nociceptivo de retirada da pata. O referido efeito nociceptivo não foi observado quando houve o tratamento prévio com MK-801 (3,6 nmol / 0,2 $\mu \mathrm{l})$ no CCA ou com lidocaína a $2 \%$ (0,2 $\mu \mathrm{l})$ na SCPd. A microinjeção de 0,2 $\mu$ l do rastreador neuronial Texas red (Peso molecular: 10.000) a $10 \%$ mostrou evidentes conexões entre o CCA e a SCPd. Dessa forma, os presentes resultados permitiram sugerir que os aminoácidos excitatórios no CCA de cobaias são capazes de diminuir a duração da resposta de IT e de facilitar a expressão do componente afetivomotivacional da dor. O mecanismo relacionado com essas atividades possivelmente envolve a ativação dos receptores glutamatérgicos do tipo NMDA presentes no CCA e o recrutamento, por conexões diretas, de neurônios presentes na SCPd. Assim, os resultados do presente estudo reforçam a idéia de que o CCA e a SCPd parecem fazer parte de uma mesma rede neural, importante para a mediação de repostas envolvidas em contextos motivacionais, que visam o afastamento ou a esquiva do animal em relação aos estímulos aversivos. 


\title{
Genética
}

\section{INVESTIGAÇÃO DE POLIMORFISMOS NOS GENES IGF2 E CYP21 EM BOVINOS DE RAÇAS ZEBUÍNAS E ANÁLISE DAS POSSÍVEIS ASSOCIAÇÕES COM CARACTERÍSTICAS DE INTERESSE ECONÔMICO}

\author{
Andréa Martins da Silva \\ Orientador: Profa. Dra. Maria Armênia Ramalho de Freitas \\ Tese de Doutorado apresentada em 05/07/2010
}

Existe um relevante interesse em pesquisar a ocorrência de polimorfismos no genoma bovino por diferentes motivos, e mais recentemente, com a finalidade de agregar mais informações ao estudo de características quantitativas visando selecionar animais geneticamente superiores com considerável valor comercial. Os polimorfismos de base única (SNPs) neste estudo foram identificados como RFLP/MboII e RFLP/HpaII sendo que o polimorfismo RFLP/MboII está situado no exon 6 do gene IGF2 (insulin-like growth factor 2), localizado no cromossomo 29 em bovinos, e desempenha um papel importante na proliferação e diferenciação celular para o crescimento e desenvolvimento dos mamíferos. O polimorfismo RFLP/HpaII encontra-se no elemento Bov-A2 (considerado um elemento SINE - Short Interspersed Nucleotide Element) presente na região promotora do gene CYP21 (Steroid 21-hydroxylase gene) no cromossomo $23 \mathrm{em}$ bovinos. Para avaliar a ocorrência dos SNPs utilizou-se a técnica de PCR-RFLP em amostras de DNA a partir de sangue/sêmen de cerca de 300 animais bovinos das raças zebuínas Gir, Guzerá e Nelore. As frequências alélicas mostraram maior incidência do alelo T quando comparado ao $\mathrm{C}$ enquanto que as frequências genotípicas apresentaram alta ocorrência do heterozigoto TC em comparação aos homozigotos CC e TT para o polimorfismo IGF2 - RFLP/MboII. Com relação ao polimorfismo CYP21 RFLP/HpaII, a frequência alélica revelou alto valor do alelo T. A população encontrou-se em equilíbrio de Hardy-Weinberg para os SNPs estudados. Ferramentas de bioinformática foram utilizadas para investigações in silico revelando que os sítios polimórficos estão em regiões com potencial regulatório. A associação desses polimorfismos com DEPs das características reprodutivas e produtivas foram investigadas, entretanto mostrou-se significativas apenas para DP550 (IGF2 RFLP/MboII) e DP450 (CYP21 - RFLP/HpaII). Os resultados obtidos sugerem que protocolos de Biologia Molecular in vitro podem ser usados para identificar novos marcadores moleculares, como SNPs funcionais adicionando informações que certamente contribuirão para estratégias de melhoramento dessas raças bovinas de grande importância para a produção de carne e leite em nosso país. Este foi o primeiro estudo sobre a ocorrência desses polimorfismos em raças zebuínas criadas no Brasil.

\section{SCI1, UM NOVO INIBIDOR TECIDO-ESPECÍFICO DA PROLIFERAÇÃO CELULAR RELACIONADO À SINALIZAÇÃO POR AUXINA}

\author{
Henrique Cestari de Paoli \\ Orientadora: Profa. Dra. Maria Helena de Souza Goldman \\ Tese de Doutorado apresentada em 12/07/2010
}

O sucesso da reprodução de plantas depende do desenvolvimento apropriado dos órgãos reprodutivos, o qual envolve redes regulatórias específicas. Realizou-se a caracterização de um gene previamente desconhecido, identificado em uma biblioteca subtrativa de estigmas/estiletes de Nicotiana tabacum. Esse gene codifica uma proteína pequena, rica em lisina, a qual mostrou-se ser específica de pistilo e, mais precisamente, transcrita nos tecidos especializados do estigma/estilete: zona secretória do estigma (SSZ) e o tecido transmissor do estilete (STT). A sequência da proteína, deduzida do cDNA, demonstrou ter dois domínios putativos de interação com ciclina, 15 sítios preditos de fosforilação (p $\geq 96 \%$ ) e um putativo sinal de localização nuclear, que foi confirmado pela localização da proteína de fusão com GFP na região intercromática/corpos nucleares. O maior nível de transcritos ocorre nos estágios bem jovens do desenvolvimento floral, em que o estigma/estilete está se diferenciando. Plantas transgênicas de RNAi e superexpressão(OE) de N. tabacum resultaram, notoriamente, em estigmas com áreas aumentadas e reduzidas, respectivamente. Cortes longitudinais do estigma/estilete maduro demonstraram que essa alteração em tamanho é uma consequência da alteração no número de células, que está aumentado nas plantas de RNAi e diminuído nas plantas OE. Juntamente com a demonstração de que 
esta proteína interage com ciclinas do tipo A, in vitro e in vivo, pôde-se concluir que esta proteína é um regulador negativo do ciclo celular, que provavelmente regula a atividade de CDK de forma tecido-específica. Com base nestes resultados, este gene foi denominado SCI1, a partir de "Ś tigma/style Cell-cycle I nhibitor $\underline{1}$ ". SCII é distinto dos inibidores de CDK já descritos em plantas e animais, propondo-se assim que este gene seja o primeiro membro de uma nova classe de inibidores de CDK, aqui definida com TICK ("Tissue-specific Inhibitors of $\underline{C} D \underline{K}$ ). As diferenças na divisão celular causadas por SCII afetaram o momento da diferenciação das células papilares, mostrando que sua diferenciação é acoplada às divisões celulares que ocorrem no estigma, consistente com um papel de SCI1 no desencadeamento da diferenciação através do controle da proliferação celular. Baseado na similaridade fenotípica entre as plantas de RNAi de $N$. tabacum e os pistilos de Arabidopsis tratados com um inibidor do transporte polar de auxina (NPA), decidiu-se analisar a expressão de três genes relacionados à via de auxina, ARF8, Aux/IAA13 e Aux/IAA19, em quatro plantas transgênicas independentes de RNAi e OE. Todos os três genes foram significativamente alterados, em até 5,1 vezes para Aux/IAA19, mostrando que $S C I 1$ influencia a regulação transcricional de alguns genes de resposta rápida à auxina. A caracterização do mutante scil, uma linhagem de inserção de T-DNA em Arabidopsis, também revelou um tecido estigmático maior devido a um aumento no número de células, como ocorre em plantas de RNAi de $N$. tabacum. Surpreendentemente, os pistilos de scil são bem semelhantes aos do duplo mutante yuc2yuc6, que perderam a habilidade de sintetisar auxina, de forma adequada, neste tecido. Cortes longitudinais e imagens de contraste de fase (DIC) mostraram que a aumentada estrutura estigmática de yuc2yuc6, assim também como a aumentada estrutura estigmática dos sinalizadores de auxina pid336 e npyl, são todas consequências do aumento no número de células. Coerentemente, o gene AtSCII tem sua expressão diminuída nos mutantes yuc2yuc6, pid336 e npyl. Testes de interação genética mostraram que scil, npyl e scilnpyl têm uma estrutura estigmática bastante semelhante entre si, enquanto que scil mostrou uma interação sinergística com yuc2yuc6 e pid336. Esses resultados consistentemente enquadram SCI1 na sinalização de auxina, que controla a divisão celular na parte superior do pistilo. Em conjunto, os resultados mostraram que $S C I 1$ é um novo inibidor de CDK, que atua como componente da via de transdução de sinal de auxina no estigma/estilete, para controlar a proliferação e diferenciação celular, representando um efetor molecular deste hormônio no desenvolvimento do pistilo.

\section{CARACTERIZAÇÃO DO GENE NTSPICE1, UM PUTATIVO INIBIDOR DA EXPANSÃO CELULAR, EXPRESSO NOS ÓRGÃOS REPRODUTIVOS DE Nicotiana Tabacum $L$}

\section{Michael dos Santos Brito}

Orientador: Profa. Dra. Maria Helena de Souza Goldman

Tese de Doutorado apresentada em 27/08/2010

Recentemente, uma análise por "macroarray" identificou um gene, clone 092H06, preferencialmente expresso em estigmas/estiletes de Nicotiana tabacum, codificando uma proteína hipotética de 68 aminoácidos (Quiapim, 2005; Quiapim et al., 2009). Após análises in silico, foi verificado que se trata de uma proteína extremamente conservada presente apenas em plantas. A análise por RT-PCR em tempo real, feita com RNA dos diferentes órgãos vegetativos e reprodutivos da planta, mostrou que este gene é específico dos órgãos reprodutivos e preferencialmente expresso nos estigmas/estiletes. O nível de expressão do gene $092 \mathrm{H} 06$ nos estigmas/estiletes e ovários, durante os 12 estágios do desenvolvimento floral, foi analisado e mostrou que os maiores níveis de expressão ocorrem no início e final do desenvolvimento floral. Em estames, o maior nível de expressão ocorre no início do desenvolvimento floral e diminui em direção a antese. Também foi verificado que o gene 092H06 encontra-se expresso nos órgãos reprodutivos, mesmo antes da total diferenciação desses órgãos. A abordagem de hibridização "in situ" mostrou que o gene 092H06 é expresso nos tecidos especializados do estigma/estilete, respectivamente, zona secretória do estigma e tecido transmissor do estilete. Foram obtidas plantas transgênicas de superexpressão e RNAi, na tentativa de identificar o que o aumento e/ou diminuição da proteína codificada pelo gene 092H06 afetaria nas plantas transgênicas quando comparadas com a planta selvagem (SR-1). As plantas de superexpressão analisadas não apresentaram alterações fenotípicas visíveis e realizaram o processo reprodutivo normalmente. Para as plantas de RNAi, duas plantas Ri 9.2 e Ri 19.3 apresentaram alterações morfológicas. Foi verificado nessas plantas um aumento de tamanho dos órgãos reprodutivos quando comparados às plantas selvagens. Posteriormente, foi verificado que este aumento de tamanho é resultado de um aumento na expansão das células dos órgãos reprodutivos, sem alterar o número de células e ou camadas celulares. Observou-se também que as plantas Ri 9.2 e Ri 19.3 são macho estéreis. Autopolinizações controladas destas plantas transgênicas, bem como a polinização cruzada de cada uma dessas plantas transgênicas, utilizando-se do pólen delas, com SR-1 não resultaram na formação de frutos Análises por microscopia de fluorescência demonstraram que houve uma alteração na morfologia dos grãos de pólen 2 das plantas transgênicas 
Ri 9.2 e Ri 19.3. Esses resultados demonstram que o gene 092H06 atua como um inibidor do mecanismo de expansão celular e foi denominado NtSPICE (Nicotiana tabacum Small Peptide Inhibitor of Cell Expansion). Utilizando-se o sistema pETSUMO, foi produzida a proteína recombinante rSPICE em grande quantidade e na fraçãp solúvel. A proteína rSPICE foi purificada por cromatografia de afinidade e está sendo utilizada para a obtenção de um anticorpo anti-SPICE em galinha. Por fim, foi feita a localização subcelular da proteína SPICE, através de fusionamento com o gene repórter GFP em ambas as extremidades da proteína. Analíses da expressão transiente de GFP-SPICE e SPICE-GFP indicaram uma possível localização desta proteína no meio extracelular ou na membrana plasmática. A utilização de protoplastos, preparados a partir de folhas infectadas com Agrobacterium tumefasciens contendo as construções GFP-SPICE e SPICE-GFP, permitiu identificar que a proteína SPICE é direcionada para a membrana plasmática. A partir do conjunto de dados obtidos neste trabalho pode-se sugerir que SPICE represente uma nova classe de peptídeos sinalizadores, atuando como um inibidor do processo de expansão celular específico dos órgãos reprodutivos de $N$. tabacum.

\title{
Ginecologia e Obstetrícia
}

\section{EXPRESSÃO IMUNOHISTOQUÍMICA DO FATOR INDUTOR DE HIPÓXIA 1-ALFA (HIF-1 $\alpha$ ) EM PACIENTES COM CÂNCER DE MAMA LOCALMENTE AVANÇADO}

\author{
Luiz Gustavo Oliveira Brito \\ Orientador: Prof. Dr. Heitor Ricardo Cosiski Marana \\ Dissertação de Mestrado apresentada em 15/07/2010
}

Objetivos: Determinar a expressão imunohistoquímica do fator indutor de hipóxia 1-alfa (HIF-1 $\alpha$ ) e suas variáveis associadas em pacientes com câncer de mama localmente avançado. Pacientes e método: Vinte e sete mulheres foram biopsiadas para diagnóstico histopatológico do carcinoma mamário e submetidas a tratamento quimioterápico pré-cirúrgico. Analisou-se a associação do HIF-1 $\alpha$ com idade, tamanho tumoral, grau histológico, estadio clínico, status hormonal e axilar, resposta clínica e patológica após tratamento quimioterápico, expressão do receptor de estrogênio, progesterona e cerbB2. Resultados: A expressão de HIF- $1 \alpha$ foi presente em $66,7 \%$ das pacientes. O único fator associado à sua presença foi o status axilar positivo $(\mathrm{p}=0,02)$, tendo permanecido durante a análise univariada. As demais variáveis não apresentaram associação estatisticamente significante. Conclusão: Existe uma associação estatisticamente significante entre o acometimento linfonodal e a presença de HIF-1 $\alpha$ em pacientes com câncer de mama localmente avançado.

\section{RELAÇÃO DO STATUS ESTROGÊNICO COM A DISTRIBUIÇÃO E EXPRESSÃO DO PEPTIDEO INTESTINAL VASOATIVO NA PAREDE VAGINAL}

\section{Lucia Alves da Silva Lara}

Orientadora: Prof ${ }^{a}$. Dra ${ }^{\mathrm{a}}$. Ana Carolina Japur de Sá Rosa e Silva

Tese de Doutorado apresentada em 16/07/2010

Introdução: O Peptídeo Intestinal Vasoativo (VIP) está envolvido no mecanismo da lubrificação vaginal e no relaxamento da musculatura lisa vaginal. O estrogênio modula a expressão do VIP em vários órgãos, mas ainda existem controvérsias quanto a relação destas duas substâncias na parede vaginal. Não se sabe se o hipoestrogenismo prejudica a lubrificação por interferir na expressão do VIP ou por provocar a desvascularização da parede vaginal. Objetivos: Avaliar a relação do status estrogênico com a distribuição e expressão do VIP na parede vaginal, correlacionar a função sexual com a expressão do VIP em mulheres normo e hipoestrogênicas e verificar o impacto do hipoestrogenismo na parede vaginal após a menopausa. Métodos: Espécimes cirúrgicos da vagina de 30 mulheres, sendo 18 normoestrogênicas (GP) e 12 na pós-menopausa (GM), submetidas a colpoperineoplastia por prolapso genital I e II. Aferidos: FSH e estradiol, prolactina e TSH. Realizou-se: HE, imunohistoquímica para receptores estrogênicos $\alpha$, VIPe CD34 para morfometria vascular. A dor coital for acessada pelo GRISS. Resultados: Houve diferença significativa no escore do receptor estrogênico alfa (RE) entre as camadas epitelial (E), lâmina própria (LP) e muscular (M) das paredes anterior e posterior da vagina entre GP e GM 


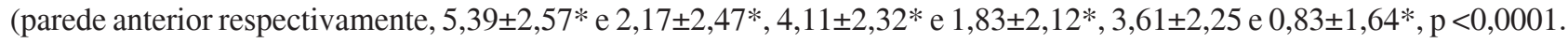

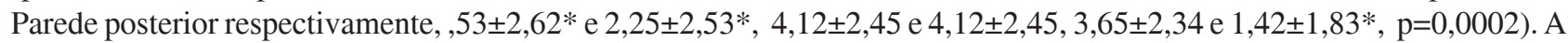
expressão do VIP na parede vaginal posterior foi significativamente maior no GP quando comparado ao GM (respectiva-

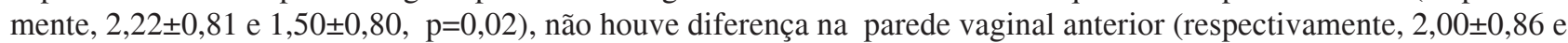
$1,50 \pm 0,79, \mathrm{p}=0,1)$. O GP apresenta concentração vascular significativamente maior do que o GM (parede anterior GP

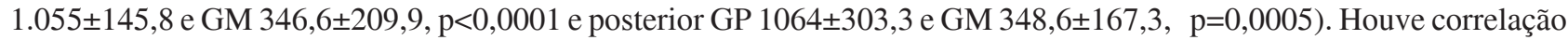
negativa entre a idade e o escore do VIP; IC 95\% -0.67 a $-0.04, \mathrm{r}=-0,40, \mathrm{p}=0,02$ e entre a idade e o escore de receptor estrogênico alfa; IC 95\% -0.65 a -0.00, r=-0.37, p=0,04. Houve correlação positiva entre o escore do receptor estrogênico alfa e a concentração de vasos da lamina própria na parede vaginal anterior (IC 95\% 0.24 a $0.91, r=0,71, p<0,009)$ e posterior (IC 95\% 0.22 a 0.91, r=0,71, p<0,0097) e correlação negativa com a idade (parede vaginal anterior IC 95\% -0.972 a -0.68, r=0,90, p<0,0001) e posterior IC 95\% -0.92 a -0.29, r=-0,74, p=0,0055). Não houve correlação entre dor coital, escore do VIP e concentrações do estradiol. E não houve correlação entre concentração de vasos e escore do VIP. Conclusão: A expressão do VIP na parede vaginal posterior se reduz com o advento da menopausa, sem entretanto haver uma correlação entre com os valores séricos do estrogênio e a expressão dos seus receptores. Parece que a idade é o fator que influencia negativamente a expressão deste neuropeptídeo na parede vaginal. Ocorre desvascularização da parede vaginal apos a menopausa sendo o hipoestrogenismo e o avançar da idade os fatores que respondem por esta alteração. A falta de correlação entre a condição estrogênica e o escore do VIP com a dor coital sugere que outro mecanismo deva influenciar no mecanismo da dor coital em mulheres menopausadas.

\title{
EXPRESSÃO DE VEGF EM TUMORES DE MAMA DE PACIENTES SUBMETIDAS À QUIMIOTERAPIA NEOADJUVANTE
}

\author{
Viviane Fernandes Schiavon \\ Orientador: Prof. Dr. Heitor Ricardo Cosiski Marana \\ Dissertação de Mestrado apresentada em 16/07/2010
}

Objetivos: A avaliação da angiogênese no câncer de mama é um importante fator prognóstico e preditivo. A expressão do fator de crescimento vascular endotelial (VEGF) tem sido relatada como metodologia adequada posto sua relação com a densidade microvascular tumoral (MVD), a dosagem de VEGF plasmático assim como com a expressão de outros genes relacionados a angiogênese. Pacientes e Métodos: este estudo avaliou 30 pacientes com diagnóstico de carcinoma de mama localmente avançado tratadas inicialmente pela quimioterapia neoadjuvante e foi correlacionada a expressão da proteína VEGF e outros caracteres clínico-patológicos destas pacientes. Resultados: A expressão da proteína VEGF foi significamente correlacionada com a resposta patológica completa $(\mathrm{p}=0,04)$. Não houve correlação entre expressão de VEGF e tamanho tumoral ( $\mathrm{p}=0,76)$, envolvimento axilar $(\mathrm{p}=0,70), \mathrm{RP}(\mathrm{p}=0,92), \mathrm{RE}(\mathrm{p}=0,98)$, superexpressão de HER-2 $(p=0,79)$, grau tumoral $(p=0,68)$ ou menopausa $(p=0,07)$. Conclusões: A expressão de VEGF foi consistentemente associada à resposta patológica completa e pode ser utilizada como fator preditivo para selecionar pacientes com CMLA para tratamento primário pela quimioterapia.

\section{MEDIADORES INFLAMATÓRIOS NA DOR PÉLVICA CRÔNICA - IDENTIFICAÇÃO DE POSSÍVEIS MARCADORES SÉRICOS DA DOENÇA}

\author{
Marcelo Gondim Rocha \\ Orientador: Prof. Dr. Omero Benedicto Poli Neto \\ Dissertação de Mestrado apresentada em 05/08/2010
}

Introdução: Dor pélvica crônica é uma doença de elevada prevalência e fisiopatologia complexa. Os métodos diagnósticos muitas vezes são insuficientes e, em decorrência, o tratamento e seguimento das mulheres é difícil. Inúmeras doenças que se apresentam com dor crônica tem um perfil inflamatório, que ainda não foi investigado para o tema em questão. Objetivos: Quantificar os níveis de óxido nítrico (NO) e das metaloproteinases 2 (MMP-2) e 9 (MMP-9) no plasma de mulheres com dor pélvica crônica. Pacientes e métodos: Foram incluídas 64 mulheres, subdivididas em 02 grupos: dor pélvica crônica e grupo controle, com 37 pacientes no primeiro grupo e 27 pacientes no segundo grupo. As pacientes do grupo de estudo eram seguidas no Ambulatório de Dor Pélvica e Endoscopia e as pacientes do grupo controle eram 
seguidas no Ambulatório de Anticoncepção do Hospital das Clínicas da Faculdade de Medicina de Ribeirão Preto - USP. Foi realizada a mensuração clínica da dor através de uma escala unidimensional (VAS) e uma escala multidimensional (McGill). Também foram preenchidas as escalas de ansiedade e depressão (HAD). Indivíduos com qualquer evidência de processos inflamatórios, hipertensão, tabagismo ou uso de contraceptivos hormonais foram excluídos. Indivíduos tomando medicação para a dor, como analgésicos ou antiinflamatórios foram solicitados a pará-los 72 horas antes de participar do estudo. Foi coletada uma amostra sanguínea de $10 \mathrm{ml}$, no ato da consulta. Esse material foi armazenado em frasco próprio com anti-coagulante, processado imediatamente no local para separação do plasma e armazenado em freezer, a 70C para mensuração subsequente. As concentrações de espécies relacionadas ao NO (nitrato) em líquidos foram medidas, sempre em triplicata, pelo método da quimioluminescência, que é um dos métodos mais simples, sensíveis e precisos disponíveis para medir NO. Foi utilizado um analisador de NO (Sievers Model 280 NO Analyzer - Boulder, CO, EUA), o qual permite medir NO em quantidades tão pequenas quanto 1 pmol. A atividade das MMP-2 e MMP-9 no plasma serão determinadas pelo método da zimografia, que consiste em uma eletroforese das amostras em um sistema SDS/PAGE que inclui o substrato da enzima (gelatina) no gel de separação, de modo a permitir a evidenciação e quantificação da atividade da enzima. Resultados: Os níveis plasmáticos de NO foram maiores nas pacientes com DPC quando comparadas às pacientes do grupo controle $(16.8 \pm 7.9$ versus $12.2 \pm 2.4$, respectivamente $(\mathrm{P}=0.0016)$. Especificamente, os níveis plasmáticos de NO foram maiores nas pacientes com DPC de origem visceral quando comparadas às pacientes com dor exclusivamente somática ou aos controles saudáveis $(19.2 \pm 8.9$ versus $12.4 \pm 1.8$ versus $12.2 \pm 2.4$, respectivamente) $(\mathrm{P}=0.0001)$. Não observamos uma correlação entre os níveis plasmáticos de NO e a duração dos sintomas (em meses) (Spearman $\mathrm{r}=$ 0.04, 95\% CI:-0.34 to 0.40, $\mathrm{P}=0.84$ ) ou com a intensidade dos sintomas dolorosos: $\mathrm{EAV}$ (Spearman $\mathrm{r}=:-0.18,95 \% \mathrm{CI}$ - 0.52 to 0.20, $\mathrm{P}=0.34$ ), ou McGill (Spearman $\mathrm{r}=-0.06,95 \% \mathrm{CI}$ :-0.41 to 0.30, $\mathrm{P}=0.72$ ). Com relação às MMP's, não houve diferença estatística entre os dois grupos. Conclusões: Os níveis plasmáticos de NO encontram-se elevados em mulheres com DPC, especialmente naquelas com dor de origem visceral. Este fato pode ser considerado uma possibilidade no seguimento de pacientes com DPC, visto que pode ser usado como um marcador sérico para a doença. Já a dosagem das MMP-s não se mostrou útil como marcador plasmático para mulheres com DPC.

\section{PERCEPÇÃO DE PROFISSIONAIS MÉDICOS SOBRE ASSISTÊNCIA DE MULHERES PORTADORAS DE DOR PÉLVICA CRÔNICA}

\section{Paula Patrícia de Souza}

Orientador: Prof. Dr. Omero Benedicto Poli Neto

Dissertação de Mestrado apresentada em 25/08/2010

A dor pélvica crônica (DPC) em mulheres é uma doença de etiologia complexa que, muitas vezes, culmina em investigações extensas e conclusões diminutas tendo, por isso, sido motivo de insatisfação e frustração de pacientes e profissionais da saúde, inclusive de conflitos entre as partes envolvidas. Muitos são os estudos que abordam as vivências da mulher portadora de dpc com a própria doença, assim como no contato médico. Nesse sentido, para compreensão ampla dessa problemática buscamos explorar como os médicos de um serviço especializado percebem e atuam frente a esse tipo de atendimento. Constituiu-se pesquisa qualitativa, sendo os dados coletados através de entrevistas semi-estruturadas e analisadas segundo Laurence Bardin, análise de conteúdo. O grupo de profissionais foi composto por sete médicos (residentes e especialistas) do Ambulatório de dor pélvica crônica do Hospital das Clínicas de Ribeirão Preto (AGDCHCFMRPUSP). O estudo apresentou como temática central a formação e prática médica, tendo sido ressaltadas subcategorias que trataram da influência das atuais práticas pedagógicas utilizadas no ensino médico, embasadas no modelo biomédico, sobre o cenário de assistência à DPC. A prática profissional tem sido caracterizada por uma abordagem reducionista, biologista, com fragmentação da assistência, o que, de certa forma, representa os resultados do modelo de formação sob o qual esses profissionais têm sido submetidos. As atuais práticas educativas relativas à saúde são embasadas no modelo biomédico, hegemônico na medicina moderna, no qual se desconhece a dimensão totalizante do ser humano, enquanto ser portador de injunções sociais, políticas, culturais, psicológicas e emocionais. Nesse sentido, faz necessária reestruturação dos paradigmas médico, a fim de que seja adotada uma visão integral para os cuidados em saúde, a partir de um modelo de assistência humanista. Esperamos que as reflexões abordadas no presente estudo possam contribuir para o desenvolvimento de um olhar crítico a respeito do ensino e práticas médicas atuais e seus efeitos sobre diversos contexto de saúde, principalmente no que concerne o atendimento a dor pélvica crônica. 


\title{
AVALIAÇÃO DA CONFIABILIDADE E CONCORDÂNCIA INTRA E INTEROBSERVADOR DE ÍNDICES VASCULARES UTILIZANDO-SE A AMOSTRA TECIDUAL ESFÉRICA VIRTUAL POR ANGIOSSONOGRAFIA TRIDIMENSIONAL NO ESTUDO DE MASSAS ANEXIAIS
}

\author{
Liliane Silvestre \\ Orientador: Prof. Dr. Francisco José Candido dos Reis \\ Dissertação de Mestrado apresentada em 26/08/2010
}

Para se avaliar a confiabilidade e concordância intra e interobservador dos índices de vascularização obtidos por meio de uma amostra tecidual esférica virtual realizada em massas anexiais, utilizando-se a angiossonografia tridimensional, foram analisadas 67 pacientes, das quais $25(37,3 \%)$ apresentavam tumores ovarianos malignos e $42(62,7 \%)$ possuíam massas ovarianas benignas. Foram calculados três índices de vascularização: índice de vascularização, índice de fluxo e índice de vascularização e fluxo. O coeficiente de correlação intraclasse (CCI) foi calculado para a análise da confiabilidade. A concordância das medidas foi verificada pelos limites de concordância de 95\% ou método de Bland e Altman. O CCI foi 0,93 (IC95\% 0,88 a 0,95) para a confiabilidade intra-observador do índice de vascularização, 0,75 (IC95\% 0,62 a 0,83) para a confiabilidade intra-observador do índice de fluxo e 0,89 (IC95\% 0,84 a 0,93) para a confiabilidade intra-observador do índice de vascularização e fluxo. O CCI foi 0,89 (IC95\% 0,83 a 0,93) para a confiabilidade interobservador do índice de vascularização, 0,76 (IC95\% 0,64 a 0,85) para a confiabilidade interobservador do índice de fluxo e 0,90 (IC95\% 0,84 a 0,93) para a confiabilidade interobservador do índice de vascularização e fluxo. Os limites de concordância de $95 \%$ intraobservador foram: -8,4 a 8,4 para o índice de vascularização, -14,5 a 13,7 para o índice de fluxo e -5,3 a 5,6 para o índice de vascularização e fluxo. Os limites de concordância de $95 \%$ interobservador foram: -9,8 a 10,9 para o índice de vascularização, $-14,0$ a 13,3 para o índice de fluxo e $-5,0$ a 5,3 para o índice de vascularização e fluxo. Concluiu-se que há excelente confiabilidade intra e interobservador para VI e VFI e boa confiabilidade intra e interobservador para FI. Foi boa a concordância entre as medidas dos índices vasculares VI e VFI intra e interobservador.

\section{TRANSIÇÃO EPITÉLIO-MESENQUIMAL E PRESENÇA DE CÉLULAS CD44+/CD24- COMO FATORES DE PREDIÇÃO DE METÁSTASE AXILAR NO CÂNCER DE MAMA INICIAL}

\author{
FernandoAntonio Mourão Valejo \\ Orientador: Prof. Dr. Daniel Guimarães Tiezzi \\ Dissertação de Mestrado apresentada em 20/09/2010
}

Sabemos hoje que os tumores sólidos apresentam uma composição celular heterogênia e que apenas uma pequena parcela dessas células apresenta capacidade de se proliferar e gerar novos tumores. Estudos prévios sobre a formação do câncer de mama têm sido realizados com base na combinação dos marcadores de superfície celular CD44 e CD24. Já foi demonstrado que uma subpopulação de células do câncer de mama com alta expressão de CD44 e baixa expressão de CD24 (CD44+/CD24-) tem maior capacidade de gerar tumores, quando comparadas com a subpopulação de células CD44-/ CD24+. O objetivo do estudo foi identificar a taxa de células com fenótipo CD44+/CD24- presentes nos tumores mamários e relacioná-la com a taxa de comprometimento dos linfonodos axilares ipsilaterais porneoplasia, além de avaliar também sua relação com outros fatores sabidamente relacionados com mal prognóstico da paciente. Pacientes e métodos: avaliamos prospectivamente 53 amostras cirúrgicas provenientes de 42 pacientes com diagnóstico histopatológico de carcinoma de mama, quantificando as células CD44+/CD24- por citometria de fluxo. Relacionamos a porcentagem destas células encontrada em cada amostra com o comprometimento axilar, os receptores hormonais e Her-2, a idade da paciente, o grau histológico do tumor, o diâmetro patológico do tumor e o tipo histológico. Resultados: verificamos um significante aumento da população de células CD44+/CD24- no grupo de carcinomas ductais invasivos em pacientes que apresentavam metástase axilar mediana 8,53\% (3,6 - 71,2\%)] em relação ao grupo de pacientes sem linfonodos comprometidos pela neoplasia [mediana $1,49 \%(0,3-17,1 \%)](\mathrm{p}=0,0002)$. Conclusão: concluímos então que quando estudamos vários tumores mamários invasivos de mesma classificação histológica, podemos notar que existe uma variação na quantidade de células CD44+/CD24- entre eles. Nosso estudo mostrou que essa variação está relacionada à agressividade tumoral e à sua capacidade de gerar metástases já que, tumores com maior quantidade de células CD44+/CD24-apresentam maior taxa de comprometimento dos linfonodos axilares. 


\title{
Imunologia Básica e Aplicada
}

\section{PESQUISA DE INFECÇÕES POR FLAVIVIRUS DA ENCEFALITE DE SAINT LOUIS, ROCIO E OESTE DO NILO EM CAVALOS, POR INQUÉRITO SOROLÓGICO E ISOLAMENTO VIRAL}

\author{
Jaqueline Raymondi Silva \\ Orientador: Prof. Dr. Luiz Tadeu Moraes Figueiredo \\ Dissertação de Mestrado apresentada em 05/07/2010
}

\begin{abstract}
Arboviroses são grave problema de saúde pública no Brasil e destas destacam-se aquelas causadas por Flavivírus, dos quais onze já foram descritos no Brasil. Destes, dois importantes em saúde pública, e que pertencem ao sorocomplexo da Encefalite Japonesa, são o vírus da encefalite de Saint Louis (SLEV) e o Rocio (ROCV). O vírus Oeste do Nilo (WNV), introduzido no continente americano em 1999, ainda não foi detectado no Brasil, contudo sua introdução é muito provável. Neste estudo, avaliou-se a circulação de SLEV, ROCV e WNV em cavalos, por tentativas de isolamento viral e inquérito soro-epidemiológico. As tentativas de isolamento viral, em 11 tecidos cerebrais de cavalos do estado da Paraíba, resultaram negativas. O inquérito sorológico, por IgG-ELISA tendo como antígeno peptídeos recombinantes do domínio III da proteína de envelope de SLEV, WNV e ROCV, foi utilizado em 753 soros de animais dos estados de São Paulo, Mato Grosso do Sul, Minas Gerais, Rio de Janeiro e Paraíba. Soros de 271 cavalos foram positivos para SLEV (35,98\%), 254 para WNV $(33,73 \%)$ e 144 para ROCV (19,12\%). Portanto, o ELISA mostrou-se adequado, diagnosticando infecções prévias por estes Flavivírus. Também, observou-se intensa circulação destes vírus infectando cavalos nos locais de estudo. Ainda, obtevese, pela primeira vez, evidencia de que WNV foi introduzido no Brasil e encontra-se a infectar cavalos nos estados pesquisados exceto Minas Gerais. Finalmente, o inquérito sorológico em cavalos mostrou-se uma abordagem adequada à vigilância das flaviviroses por SLEV, ROCV e WNV no Brasil.
\end{abstract}

\section{EXPRESSÃO GÊNICA DE MOLÉCULAS ASSOCIADAS COM A MODULAÇÃO DO SISTEMA IMUNE, QA1, QA2, QA10 E AIRE, DURANTE A ONTOGENIA DE ÓRGÃOS LINFÓIDES MURINOS}

\author{
Breno Luiz Melo Lima \\ Orientador: Prof. Dr. Eduardo Antônio Donadi. \\ Dissertação de Mestrado apresentada em 08/07/2010
}

Qa-2 e Qa-1 são moléculas murinas não-clássicas do MHC de classe I e são os homólogos funcionais do HLA-G e HLA-E, respectivamente. Essas moléculas estão envolvidas na modulação do sistema imune através da inibição da ação de células T CD8 ${ }^{+}$e células NK pela interação com receptores de inibição. Outra molécula não-clássica do MHC de classe I, a molécula Qa10 é característica do fígado e pode ser encontrada em altas concentrações na circulação. O Aire (autoimmune regulator) é o regulador transcricional responsável pela expressão de milhares de antígenos tecido-específicos da medula tímica promovendo o fenômeno de expressão gênica promíscua durante o processo de seleção negativa de timócitos. Falhas na expressão do Aire estão relacionadas com a ocorrência de graves manifestações autoimunes. Com o objetivo de caracterizar a expressão de genes envolvidos na modulação das respostas imunes, o presente estudo avaliou a expressão gênica de H2-Q7(Qa-2), H2-T23(Qa-1), H2-Q10(Qa10) e Aire durante o desenvolvimento fetal e pós-natal do timo, de órgãos linfóides periféricos e de sítios imunologicamente privilegiados em animais das linhagens C57BL/6 e BALB/c. Foram obtidas amostras de RNA dos órgãos durante o período fetal (E13.5 a E20.5) e pós-natal (1, 5, 10, 15, 45 e 60 dias). A quantificação da expressão gênica foi realizada pela técnica de PCR em tempo-real e os resultados expressos em escala de quantificação relativa $(\mathrm{QR})$ calculados através do método $2^{-\mathrm{A} A ̈ C t}$. No timo, transcritos para o gene $H 2-Q 7$ foram detectados em níveis elevados ao longo de todo o desenvolvimento, com níveis aumentados na fase adulta $(\mathrm{P}<0,001)$. No período fetal, $H 2-Q 7$ foi mais expresso em timo fetais com E20.5 dias $(\mathrm{P}<0,05)$, período de ocorrência dos processos de seleção tímica. Os perfis de expressão de $H 2-Q 7$ no timo, e em órgãos linfóides periféricos, mostraram padrões distintos, caracterizado pelo aumento gradativo nos níveis de transcritos de acordo com o avanço da idade do animal. O perfil de expressão de H2-T23 se manteve sem grandes variações ao longo da ontogenia do timo. Fígado e intestino, respectivamente, foram os órgãos que expressaram os níveis mais elevados de $H 2-T 23$ com tendência ao aumento de acordo com a idade ( $<<0,001)$. O gene $H 2-Q 10$ foi expresso preferencialmente pelo fígado em níveis 5 vezes mais elevados na fase adulta. A análise do perfil de expressão de Aire no timo mostrou que o pico de expressão desse gene ocorreu por volta do dia E16.5 em animais C57BL/6, e dia E18.5 em BALB/c ( $\mathrm{P}<0,001)$. Em ambas as linhagens, a expressão de Aire foi detectada, em níveis diminuídos, durante a fase adulta do timo e, ainda, em órgãos linfóides periféricos em diferentes idades. Na placenta, de maneira 
geral, os níveis de mRNA de todos os genes diminuíram com o avanço da gestação. No cérebro não detectamos níveis consideráveis de genes de classe Ib. De maneira geral, as linhagens C57BL/6 e BALB/c apresentaram perfis de expressão gênica semelhantes, entretanto, com níveis de transcritos diferentes, variando de acordo com a fase de desenvolvimento de cada órgão. Esses resultados sugerem que genes não-clássicos do MHC começam a ser expressos cedo durante a ontogenia dos órgãos linfóides e os seus níveis variam de acordo com a idade do animal, podendo estar relacionados com a manutenção dos mecanismos atuantes na manutenção da tolerância imunológica.

\title{
PAPEL DE CCR5 NA INFECÇÃO ORAL POR Toxoplama gondii
}

\author{
Giuliano Bonfá \\ Orientador: Prof. Dr. João Santana da Silva \\ Dissertação de Mestrado apresentada em 26/07/2010
}

Toxoplasma gondii é um protozoário intracelular obrigatório que causa a toxoplasmose. Em modelo experimental, camundongos C57BL/6 infectados por via oral com 100 cistos de T. gondii, cepa ME-49, desenvolvem sérias lesões intestinais similares as observadas em doenças inflamatórias intestinais. Ao invadir as células epiteliais intestinais, o parasito induz uma resposta inflamatória de padrão T "helper" (Th) 1 elevada, ativada pela produção de quimiocinas e citocinas envolvidas na migração e ativação celular. Para que ocorra essa migração celular para o sítio de infecção é necessário a presença de receptores de quimiocinas. O receptor de quimiocinas CCR5 é muito importante para o recrutamento celular em algumas infecções e está envolvido com a migração de vários subtipos celulares como células dendríticas, células T e, em particular, células T reguladoras. CCR5 pode estar relacionado também a mecanismos independentes

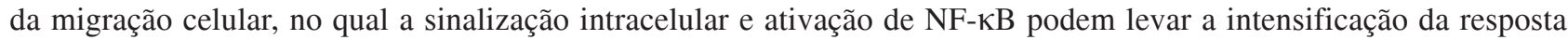
imunológica. Ainda não está claro o papel do receptor CCR5 no modelo de infecção oral por T. gondii. Dessa forma, animais C57BL/6 e deficientes em CCR5 foram infectados por via oral com 5 cistos de T. gondii, cepa ME-49, e alguns parâmetros imunológicos e bioquímicos foram avaliados no $8^{\circ}$ dia de infecção. Os resultados mostraram que animais $\mathrm{CCR}^{-/-}$apresentaram alta suscetibilidade à infecção oral por T. gondii, exibindo um intenso infiltrado inflamatório no íleo e regiões de ulceração epitelial, quando comparados com animais C57BL/6. Independentemente de serem deficientes ou não de CCR5, os camundongos apresentaram focos inflamatórios dispersos pelo parênquima do fígado, entretanto camundongos CCR5 ${ }^{-/}$apresentaram uma extensiva vacuolização dos hepatócitos, com excessivo acúmulo de lipídeos no órgão e elevada concentração sérica de triglicérides e de transaminases. A carga parasitária foi significativamente mais elevada no intestino delgado e no fígado dos animais CCR5 ${ }^{-/-}$em comparação com animais C57BL/6. Foi observada também uma menor migração de células NK no intestino delgado, bem como um aumento na frequência de células T CD4+ neste órgão e uma menor concentração de IFN- $\gamma$ e IL-12p40 no macerado do fígado dos animais CCR5 ${ }^{-/}$em comparação com C57BL/6. Análise de expressão gênica no fígado revelou redução na formação de transcritos para PPAR $\alpha$ nos animais deficientes em CCR5, e quando os camundongos foram tratados com Gemfibrozil, um agonista de PPAR $\alpha$, houve reversão na vacuolização hepática e na concentração de triglicérides no soro dos animais CCR5 ${ }^{-1}$. Estes dados sugerem que a migração celular dependente de CCR5 é essencial para a modulação da resposta inflamatória induzida por T. gondii no intestino delgado. Além do mais, a ausência de CCR5 compromete a integridade hepática durante a infecção oral por T. gondii e os mecanismos moleculares envolvidos podem estar relacionados à expressão de PPAR $\alpha$.

\section{ANÁLISE DOS EFEITOS ANTIANGIOGÊNICOS E ANTIPROLIFERATIVOS DA HALOFUGINONA NA LEUCEMIA PROMIELOCÍTICA AGUDA}

\author{
Patrícia Aparecida de Assis
}

Orientador: Prof. Dr. Eduardo Magalhães Rego

Dissertação de Mestrado apresentada em 03/08/2010

Angiogênese é o termo utilizado para descrever o crescimento de novos vasos sanguíneos a partir dos já existentes. Vários estudos demonstraram a densidade microvascular (DMV) como um fator prognóstico nas leucemias, em particular, leucemia promielocítica aguda (LPA). Este subtipo de leucemia corresponde a cerca de 20 a $25 \%$ das leucemias mielóides agudas nos países latino-americanos e apresenta características clínicas, morfológicas e biológicas peculiares. A halofuginona (HF), originalmente descrita como um agente antifúngico apresenta capacidade de inibir o crescimento tumoral e formação de vasos em modelos animais de tumores sólidos. Estudos realizados por nosso grupo demonstraram que a HF inibiu a secreção do VEGF e a proliferação de linhagens celulares de LPA. Desta forma, o presente trabalho teve 
por objetivo determinar o potencial antiproliferativo e antiangiogênico da HF em um modelo experimental in vivo da LPA e avaliar os mecanismos subjacentes a sua ação. Primeiramente, a análise do ciclo celular em células NB4 tratadas com HF apresentou significativa diminuição da proliferação celular (2,093 $\pm 0,304$ vs. 41,21 $\pm 3,25)$, juntamente com um aumento significativo da apoptose (12,53 $\pm 1,53$ vs. $21,95 \pm 0,79 ; p=0,0007)$. Por meio da técnica de Real Time Array foi possível identificar dois grupos de genes associados a apoptose celular diferencialmente expressos em células tratadas com HF: TNF, TNFRSF9, TNFTSF10B, CD40, FAS, CASP10, CASP8 e CASP3, sugerindo que a HF induz a via extrínseca de apoptose. A análise in vivo da HF foi realizada em camundongos NOD/SCID previamente irradiados e transplantados com células leucêmicas PML-RAR $\alpha$ murinas. Camundongos tratados com HF, por 21 dias após o transplante não apresentaram remissão molecular, determinada pela amplificação do gene PML-RARA por PCR, porém foi observada menor infiltração leucêmica em relação aos camundongos não tratados (Leucócitos: 4,2 $\pm 3,89$ vs. 20,6 $\pm 21,9$; p <0.0001); Hemoglobina: 12,0 $\pm 1,40$ vs. $9,6 \pm 1,67 ; \mathrm{p}<0.0001$; e Plaquetas: $932,0 \pm 122,5$ vs. 552,0 $\pm 83,2 ; \mathrm{p}<0.001$ respectivamente) e um menor peso relativo do baço ( 0,006 vs. $0,012, \mathrm{p}=0,0415)$. Ademais, a contagem diferencial e imunofenotipagem da medula óssea evidenciaram menor porcentagem de células mielóides imaturas (16,88 $\pm 6,27 \mathrm{vs.} 44,06 \pm 27,06)$. A HF também foi capaz de inibir a fosforilação de SMAD2 e consequentemente bloquear a via do TGF- $\beta$ em células NB4. No entanto, animais leucêmicos apresentaram menor nível sérico de TGF- $\beta$ em relação aos saudáveis e tratados $(475,58$ vs. 1.378,45/1.146,82 pg/mL; $\mathrm{p}<0,0001)$, sugerindo que o blasto leucêmico produz esta citocina e a diminuição de células leucêmicas resultou em diminuição dos níveis séricos de TGF- $\beta$. A HF não aumentou a sobrevida dos animais leucêmicos e a elevação das enzimas hepáticas sugeriu que o tratamento foi hepatotóxico. Por fim, com relação à angiogênese, a análise da expressão gênica mostrou que o tratamento com HF inibiu a expressão de VEGF e EGF e o estudo por imunohistoquímica de seções da medula óssea evidenciou menor expressão $\operatorname{VEGF}(30$ vs. $80 \%, \mathrm{p}=0,0227)$, porém não houve diminuição da DMV. O conjunto desses resultados mostrou que a angiogênese é um importante alvo terapêutico na LPA, e que apesar da toxicidade, a HF apresenta potencial antileucêmico, tanto por conta de seus efeitos antiproliferativos e próapoptóticos, quanto por sua capacidade de inibir a produção de fatores próangiogênicos.

\title{
AVALIAÇÃO DO CAMUNDONGOS C57BL/6 COMO MODELO MURINO PARA ESTUDO DA INFECÇÃO PELO VÍRUS DA DENGUE
}

\author{
Rafael de Queiroz Prado \\ Orientador: Prof. Dr. Victor Hugo Aquino Quintana \\ Dissertação de Mestrado apresentada em 05/08/2010
}

A dengue é uma doença infecciosa de grande importância em saúde pública em países tropicais e subtropicais. Segundo a Organização Mundial de Saúde, cerca de 50 a 100 milhões de pessoas se infectam anualmente em mais de 100 países de todos os continentes. A dengue apresenta-se em três formas clínicas principais; doença febril indiferenciada, febre clássica do dengue (DF) e dengue hemorrágica com ou sem choque (DHF/DSS). A patogênese da doença, porém, ainda não é bem esclarecida e a falta de um modelo animal que apresenta aspectos característicos da infecção é um dos maiores obstáculos. Neste trabalho, avaliamos o potencial de camundongos C57BL/6 como modelo murino para estudo da infecção por dengue, através da analise de variáveis clínicas, laboratoriais e imunológicas. Após infectar os animais com DENV-1 (Mochizuki), detectamos o genoma viral no plasma, cérebro, fígado, rim e baço. Foi verificada plaquetopenia e evidências de dano hepático induzida pela infecção. Na caracterização da resposta imune contra o vírus, observamos a presença de anticorpos neutralizantes e aumento da porcentagem do número de macrófagos no baço dos animais infectados. Através de experimentos de transferência passiva de anticorpos heterotípicos, verificamos aumento da carga viral no plasma de camundongos infectados com sorotipo heterólogo. Desse modo, embora os camundongos não apresentam as características clínicas da doença observada em humanos, concluímos que camundongos C57BL/6 podem ser utilizados como modelo de estudo da infecção pelo vírus dengue.

\section{AÇÃO DA CLOROQUINA SOBRE A REPLICAÇÃO DO VÍRUS DENGUE-2 EM CÉLULAS DE LINHAGEM MONOCÍTICAS E EM MACACOS AOTUS}

\section{Kleber Juvenal Silva Farias}

Orientador: Prof. Dr. Benedito Antônio Lopes da Fonseca

Tese de Doutorado apresentada em 11/08/2010

Os vírus dengue pertencem à família Flaviviridae, possuem um genoma RNA de polaridade positiva, fita simples, e é transmitido pelos mosquitos Aedes aegypti e Aedes albopictus. Representam os mais importantes arbovirus causado- 
res de doença em humanos, resultando em progressivas manifestações clínicas tais como febre da dengue, febre hemorrágica da dengue e síndrome do choque da dengue. O controle desta virose é feito apenas pelo controle do vetor, pois não existe até o momento, nenhuma vacina que proteja os indivíduos desta virose e nenhum antiviral para o controle da replicação viral. Este trabalho tem como objetivo estudar o efeito da cloroquina sobre a replicação do vírus dengue-2 (New Guinea $C$ ) em cultura de células de linhagem monocítica (U937) e em primatas do novo mundo do gênero Aotus. Para atingir tais objetivos utilizou-se camundongos Swiss recém-nascidos de 1 a 2 dias de idade para a amplificação do vírus dengue-2 no cérebro destes animais e o cultivo de células C6/36, sendo que as monocamadas confluentes destas células foram infectadas com vírus dengue-2, a uma multiplicidade de infecção (MOI) de 0,1 pfu por célula. A confirmação da infecção viral do macerado de cérebro de camundongos Swiss recém-nascidos e da cultura celular, foi realizado diretamente por meio de uma RT-PCR e indiretamente por imunofluorescência indireta, respectivamente. A avaliação da inibição da replicação viral pela cloroquina (aumenta o pH endossomal) foi realizada em células U937 tratadas 1 hora após a infecção viral e em intervalos de 24-24 e 12-12 horas. Sobrenadantes das células infectadas foram coletados após períodos de 24, 48, 72, 96, 120, 144 e 168 horas da infecção viral. Foi realizada a extração do RNA total do sobrenadante através do Kit QIAamp® RNA Viral (QIAGEN®, USA). A replicação viral foi analisada através da quantificação dos vírus produzidos pela detecção do número de cópias de RNA do vírus dengue-2 e por imunofluorescência indireta. A quantificação foi realizada por PCR em tempo real e por ensaio de placa (PFU). Para verificar a ação da droga in vivo no sentido de investigar o seu possível uso em humanos, grupos de 20 primatas Aotus azarai infulatus foram desafiados por via subcutânea com uma cepa virulenta do vírus dengue-2, e tratados ou não 2 dias após a infecção com a cloroquina por via oral, sendo que a droga foi administrada em intervalos de 24 horas durante dez dias. Os animais foram observados durante 30 dias. Foram investigados parâmetros clínicos tais como, febre e alteração do comportamento. A viremia foi analisada por RT-PCR e a dosagem das citocinas inflamatórias (IL-2, IL-4, IL-5, IL-6, TNF- $\alpha$ e IFN- $\gamma$ ) foi realizada por Cytometric Bead Array (CBA) utilizando o kit de citocinas Th1/Th2 de primatas não-humanos (BD), e a análise do monitoramento dos níveis séricos das aminotransferases: Alanina aminotransferase (ALT) e Aspartato aminotransferase (AST) realizados por métodos convencionais. Este estudo fornece subsídios para que possamos, em um próximo estudo, investigar o uso da cloroquina em seres humanos infectados pelos vírus dengue.

\section{AVALIAÇÃO DE UM MODELO ANIMAL PARA ESTUDO DA INFECÇÃO PELO VÍRUS DA DENGUE}

\section{Eric Almeida Xavier}

Orientador: Prof. Dr. Víctor Hugo Aquino Quintana

Dissertação de Mestrado apresentada em 18/08/2010

A dengue é a arbovirose (doença viral transmitida por artrópodes) mais difundida em países tropicais e subtropicais. Segundo a Organização Mundial da Saúde, estima-se que mais de 100 milhões de casos ocorrem anualmente em todo o mundo.

Com base em testes sorológicos, os vírus da dengue são classificados em quatro sorotipos antigenicamente distintos (DENV-1, DENV-2, DENV-3 e DENV-4). A infecção de humanos com qualquer um dos quatro sorotipos de dengue pode levar ao desenvolvimento de três formas clínicas principais; doença febril indiferenciada, febre clássica da dengue (FD) e dengue hemorrágica com ou sem choque (DHF/DSS).

Trabalhos anteriores ao usarem a linhagem de camundongos C57black/6 obtiveram resultados como hemorragia intraperitoneal e injuria ao fígado dos animais infectados, portanto foi de interesse estudar como se desenvolve a infecção por DENV-1 nestes animais. Então o objetivo principal foi estudar a infecção pelo DENV-1 em camundongos C57BL/6 inoculados via intraperitoneal. Foi analisada a presença do vírus DENV-1 em diferentes órgãos cérebro, Baco, fígado e rim além do soro dos animais C57 Black/6 imunologicamente competentes, pois trabalhos realizados anteriormente por diversos grupos de pesquisa da área tem resultados controversos mostrando que a detecção posterior do DENV seria dependente de fatores como carga viral, tipo de animal infectado e principalmente da cepa viral utilizada. Como principais conclusões de nosso trabalho os animais C57BL/6 selvagem infectados com o DENV-1 mochisuki apresentaram carga viral detectável até o décimo sexto dia. O animal C57BL/6 selvagem pode ser usado como modelo experimental para infecção com DENV. 


\title{
PAPEL DA ENZIMA 5-LIPOXIGENASE DURANTE A INFECÇÃO EXPERIMENTAL POR Paracoccidioides brasiliensis
}

\author{
Fabrine Sales Massafera Tristão \\ Orientador: Prof. Dr. João Santana da Silva \\ Tese de Doutorado apresentada em 22/09/2010
}

Leucotrienos e lipoxinas são mediadores lipídicos sintetizados a partir do metabolismo do ácido araquidônico pela enzima 5-lipoxigenase (5-LO). Nos últimos anos, vários trabalhos vêm demonstrando que estes mediadores atuam como moduladores dos mecanismos de defesa do hospedeiro contra agentes infecciosos. A paracoccidioidomicose (PCM) é uma doença sistêmica, de evolução crônica e granulomatosa, causada pelo fungo termodimórfico Paracoccidioides brasiliensis. Considerando que pouco se sabe sobre os mecanismos que desencadeiam uma resposta imune eficiente durante a PCM, buscamos no presente trabalho avaliar o papel da 5-LO durante a infecção experimental por $P$. brasiliensis. Para isso, camundongos B6.129 e geneticamente deficientes de 5- $\mathrm{LO}\left(5-\mathrm{LO}^{\mathrm{KO}}\right)$ foram infectados intravenosamente por $1 \times 10^{6}$ formas leveduriformes da cepa altamente virulenta 18 de $P$. brasiliensis (Pb18). Inicialmente, notamos que a mortalidade em ambos os grupos teve início por volta dos 40 dias de infecção (dpi); todavia, 100\% dos camundongos B6.129 haviam sucumbido à infecção antes do $100^{\circ}$ dia, enquanto aproximadamente $30 \%$ dos animais $5-\mathrm{LO}^{\mathrm{KO}}$ continuaram vivos até o fim do experimento ( $110 \mathrm{dpi}$ ). Corroborando com a maior sobrevida, animais 5-LO ${ }^{\mathrm{KO}}$ apresentaram melhor controle do crescimento fúngico, bem como uma resposta inflamatória menos exacerbada e mais organizada, evidenciando lesões

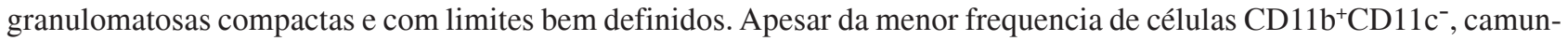
dongos 5-LO ${ }^{\mathrm{KO}}$ apresentaram uma maior produção de óxido nítrico (NO), um importante metabólito envolvido na morte de leveduras. Inversamente à maior expressão de óxido nítrico sintase (NOS-2), encontramos no pulmão de camundongos 5$\mathrm{LO}^{\mathrm{KO}}$ níveis mais baixos de transcritos para arginase-1, uma enzima competidora por substrato com a NOS-2, e que está diretamente envolvida com a diferenciação de células T reguladoras (Treg). Quando fenotipamos os linfócitos presentes no tecido pulmonar de camundongos 5-LO ${ }^{\mathrm{KO}}$ infectados, de fato encontramos um menor número de Treg, associado a um maior número de linfócitos T CD4+ expressando, preferencialmente, o fator de transcrição T-bet, característico de células Th1. Em concordância, camundongos 5-LO ${ }^{\mathrm{KO}}$ apresentaram maior produção de IFN- $\gamma$ e IL-12 no homogenado pulmonar, indicando a predominância de um perfil Th1 protetor de resposta nestes animais. Vários estudos afirmam que a presença de anticorpos específicos para $P$. brasiliensis está associada com doença grave e, de fato, detectamos uma menor produção de IgG total e dos subtipos IgG1, IgG3, IgG2a e IgG2b no soro de animais 5-LO ${ }^{\mathrm{KO}}$ em relação ao grupo B6.129. Quando dosamos leucotrienos $\left(\mathrm{LTB}_{4}\right)$ e lipoxinas $\left(\mathrm{LXA}_{4}\right)$ no homogenado pulmonar de camundongos B6.129 infectados por $P$. brasiliensis, nossos dados apontaram para a síntese preferencial de $\mathrm{LXA}_{4}$ pela via 5-LO, o que sugere seu envolvimento com a maior susceptibilidade observada nestes animais. De fato, quando tratamos camundongos B6.129 com BOC-2, um antagonista do receptor de lipoxina, encontramos aos 15 e 30 dpi um menor número de colônias fúngicas no tecido pulmonar, em associação com maior produção de NO quando comparados com animais B6.129 não tratados. Assim, tomados em conjunto, nossos resultados demonstram que a síntese de lipoxina pela via 5-lipoxigenase confere susceptibilidade durante a infecção experimental por $P$. brasiliensis.

\section{Neurologia}

\section{DOR CRÔNICA DIFUSA, SINTOMAS DE DEPRESSÃO E QUALIDADE DE VIDA RELACIONADA À SAÚDE EM MULHERES COM MIGRÂNEA}

\author{
Juliana Stuginski Barbosa \\ Orientador: Prof. Dr. Jose Geraldo Speciali \\ Dissertação de Mestrado apresentada em 05/07/2010
}

O objetivo deste estudo foi verificar a presença de dor crônica difusa, pontos dolorosos à palpação e de sintomas de depressão e seu impacto na qualidade de vida relacionada à saúde (QVRS) em mulheres com migrânea, episódica ou 
crônica, e comparar estes dados com um grupo de mulheres sem cefaleia. Duzentas e oitenta e seis pacientes com cefaleia, atendidas em primeira consulta no Ambulatório de Cefaleia e Algias Craniofaciais do Hospital das Clínicas da Faculdade de Medicina de Ribeirão Preto foram convocadas por carta a comparecerem em horário e data marcados com acompanhantes do sexo feminino. Destas, 143 (50\%) pacientes e 93 acompanhantes compareceram. Aplicados critérios de inclusão e exclusão, compuseram a casuística 53 pacientes com migrânea episódica (ME), 37 com migrânea crônica (MC) e 89 mulheres sem histórico de cefaleia (grupo controle). Questões sobre dor crônica difusa e exame físico para detecção de pontos dolorosos à palpação (tender points) foram realizados baseados nos critérios de diagnóstico do Colégio Americano de Reumatologia (ACR). Para verificação dos sintomas de depressão foi aplicado o Inventário de Depressão de Beck (BDI) e para QVRS o questionário SF-36, analisado em escore total e nos oito domínios. Os resultados encontrados apontam que o relato de dor crônica difusa foi mais frequente em pacientes com migrânea do que no grupo controle. $\mathrm{O}$ número médio de tender points e a média do escore do BDI encontrados não diferiu entre os grupos MC e ME, mas foi significantemente maior do que no grupo controle. Os grupos com migrânea apresentaram significativamente os menores escores em relação ao grupo controle, na média total da pontuação obtida no questionário SF-36. O grupo MC apresentou os menores escores em todos os domínios do SF-36. A presença de pontos doloridos à palpação não esteve correlacionada com o escore do BDI, ou com o escore do SF-36. Mas os escores do BDI estiveram correlacionados ao escore do SF-36 de forma significativa em todos os domínios do questionário nos grupos MC e controle. Por regressão quantílica verificouse que a o escore do questionário SF-36 se manteve pior de forma significativa no grupo MC em relação ao grupo controle, sendo influenciado pelo escore do BDI. Este estudo demonstrou que dor crônica difusa é relatada por um maior número de mulheres com migrânea, sobretudo com a forma crônica. Ainda, as mulheres com migrânea apresentaram maior número de pontos doloridos à palpação (tender points), sintomas de depressão e pior qualidade de vida relacionada à saúde (QVRS) quando comparadas à mulheres sem relato de cefaleia. Os sintomas de depressão estiveram correlacionados a pior QVRS no grupo MC e controle. A QVRS é significativamente pior no grupo MC em relação a indivíduos sem cefaleia, e esta relação é dependente da presença de sintomas de depressão.

\title{
CARACTERÍSTICAS CLÍNICAS E VALIDAÇÃO DE INSTRUMENTOS PARA IDENTIFICAÇÃO DE DEPRESSÃO MAIOR NA DOENÇA DE PARKINSON
}

\author{
Marcos Hortes Nishiara Chagas \\ Orientador: Prof. Dr. Vitor Tumas \\ Dissertação de Mestrado apresentada em 23/07/2010
}

Introdução: A depressão é a comorbidade psiquiátrica mais comumente associada à doença de Parkinson (DP), afetando até $68,1 \% \%$ dos pacientes. No entanto, tal condição é frequentemente subdiagnosticada e subreconhecida, e dificilmente o paciente acometido recebe tratamento para este transtorno psiquiátrico. Objetivos: O objetivo do presente estudo foi avaliar no nosso meio a prevalência de depressão maior na DP e validar instrumentos de identificação de depressão maior na DP. Métodos: O estudo foi realizado no ambulatório de transtornos do movimento do Hospital das Clínicas da Faculdade de Medicina de Ribeirão Preto - USP. Foram selecionados 110 pacientes consecutivos com diagnóstico de DP, que foram entrevistados independentemente por um psiquiatra treinado por meio de uma entrevista clínica estruturada dirigida para os critérios do DSM-IV (SCID-CV). Além disso, foram aplicadas as seguintes escalas de rastreamento de depressão: Escala de depressão auto-aplicável de Zung (SDS), escala de depressão geriátrica com 15 itens (GDS15), questionário sobre a saúde do paciente (PHQ-2 e PHQ-9). Foram excluídos aqueles pacientes com quadro demencial associado à DP. Resultados: A prevalência atual encontrada para depressão foi de 25,5\% $(\mathrm{N}=28)$ e a prevalência na vida foi de 57,3\% (N=63). Em relação ao gênero, a prevalência atual e na vida de depressão foi mais comum no sexo feminino, sendo esta diferença estatisticamente significativa $(\mathrm{p}<0,01)$. Não houve relação estatística entre a presença de depressão e a gravidade dos sintomas motores. Os escores da SDS, GDS-15, PHQ-9 e PHQ-2 discriminaram bem os sujeitos com e sem depressão maior. A validade convergente da SDS, PHQ-9 e PHQ-2 em relação à GDS-15 foi, respectivamente, de 0,67, 0,63 e 0,61. Conclusões: A alta prevalência de depressão maior em pacientes com DP é comparável com a taxa observada em estudos. Estratégias de diagnóstico precoce e tratamento adequado parecem necessários e oportunos, visando melhorar a qualidade de vida dos pacientes e evitar possíveis complicações. Todos os instrumentos aferidos mostraram-se válidos para a identificação de depressão maior em pacientes com DP. 


\title{
ANÁLISE DA INTERAÇÃO ENTRE AVALIAÇÕES DA FUNÇÃO OTOLÍTICA: POTENCIAL MIOGÊNICO EVOCADO VESTIBULAR (VEMP) E SUBJETIVA VERTICAL VISUAL (SVV)
}

\author{
Martha Funabashi \\ Orientador: Prof. Dr. Osvaldo Massaiti Takayanagui \\ Dissertação de Mestrado apresentada em 26/07/2010
}

O sistema vestibular, juntamente com outros sistemas, atua no equilíbrio, controle postural, orientação espacial e estabilização do olhar. Os otólitos são responsáveis pela percepção da inclinação cefálica e aceleração linear cujos sinais são utilizados pelo sistema nervoso central para alinhar a cabeça em relação ao eixo gravitacional. O sáculo é um otólito muito sensível à ação da gravidade e contribui significantemente para os reflexos vestíbulo-ocular e vestíbulo-cólico, além de possuir células auditivas. Diversos exames avaliam a integridade do sáculo e das vias otolíticas, mas a interação entre estes ainda não foi estabelecida. O objetivo do presente estudo foi analisar a interação destes métodos de avaliação de funções otolíticas: potencial miogênico evocado vestibular (VEMP) e subjetiva vertical visual (SVV). Para isso, o estudo realizou as duas avaliações em 41 indivíduos (15 voluntários saudáveis, 14 com hidropsia endolinfática bilateral, 6 com déficit do canal semicircular horizontal bilateral e 6 indivíduos com hidropsia endolinfática ou déficit do canal semicircular horizontal unilateral). A partir de estímulos sonoros tone bursts de $7 \mathrm{~ms}$ (subida/descida: $2 \mathrm{~ms}$, platô: $3 \mathrm{~ms}$ ), frequência de $500 \mathrm{~Hz}$, apresentados na taxa de $5 \mathrm{~Hz}$, com intensidade de $110 \mathrm{~dB}$, foram registrados os potenciais miogênicos evocados no músculo cervical esternocleido-mastoideo. O exame foi finalizado após 200 promediações. As respostas foram analisadas por meio da morfologia, demarcando-se as ondas p13 e n23, pelas latências e amplitude dos primeiros picos positivo e negativo. Em seguida, foi obtido o índice de assimetria e os resultados comparados entre os grupos. Para a realização da SVV, foi utilizado um computador de 15.4" onde era projetada uma barra luminosa de $7 \mathrm{~cm}$ em um fundo branco. Essa imagem era visualizada pelo voluntário através de um tubo circular escuro para privar o mesmo de qualquer referência visual que pudesse orientá-lo sobre a vertical real. Foram realizadas seis medidas e o valor médios destas foi considerada a variável utilizada para análise. Para os voluntários com acometimento bilateral, foi considerado o valor em módulo das medidas. Ao aplicar o teste de correlação de Spearman, não foi encontrada nenhuma relação linear entre as variáveis numéricas da prova calórica, desvio da SVV e os valores de latência e amplitude do VEMP ( $>0,05)$. Aplicando o teste de McNemar e em seguida a análise de concordância de Kappa, verificou-se: moderada associação entre a presença de desvios da SVV e alteração da latência de n 23 e índice de assimetria em voluntários dos grupos 2 e 3, moderada associação entre a presença de alteração da prova calórica e da latência de p13 e moderada associação entre a presença de desvios da SVV e alteração dos parâmetros do VEMP. Baseados nesses dados, nosso estudo mostra que há associação entre a presença de disfunção vestibular, tanto unilateral quanto bilateral, com a presença de alteração da amplitude das latências das ondas do VEMP, assim como com presença de desvio da SVV. Em pacientes com acometimento bilateral, não há associação entre presença de alteração na prova calórica bitérmica com a presença de alteração da SVV ou do VEMP, porém há associação entre a presença de desvios da SVV com a presença de alteração da latência de n23 e índice de assimetria do VEMP. Em pacientes com acometimento unilateral, há associação entre a presença de alteração na prova calórica bitérmica com alteração da latência da onda p13, assim como há associação entre a presença de desvios da SVV e alteração de todos os parâmetros do VEMP.

\section{COMPORTAMENTO DA PRESSÃO ARTERIAL SISTÊMICA E DA FREQUÊNCIA CARDÍACA DURANTE A FASE DE DOR DA MIGRÂNEA}

\author{
Fabíola Dach \\ Orientador: Prof. Dr. Jose Geraldo Speciali \\ Tese de Doutorado apresentada em 02/08/2010
}

Objetivos: Avaliar o comportamento da pressão arterial (PA) e da frequência cardíaca (FC) durante a fase de dor da migrânea em pacientes sem hipertensão arterial sistêmica (HAS). Avaliar essas variáveis em função da intensidade de dor e se elas sofrem influência do uso agudo de ibuprofeno. Métodos: Dez pacientes (nove mulheres), entre 21 e 43 anos, com diagnóstico de migrânea foram selecionados. Todos tinham diagnóstico de migrânea sem aura e quatro deles também tinha diagnóstico de migrânea com aura. Eles apresentavam de 3 a 11 dias de dor por mês, não tinham qualquer outro problema de saúde e não estavam em tratamento profilático para migrânea. Além disso, não utilizavam medicamentos que pudessem interferir na PA ou FC. Os pacientes foram submetidos à anamnese e exame físico. Para descartar HAS, foram submetidos 
a medições convencionais da PA e Medidas Ambulatoriais da Pressão Arterial por 24h. A aquisição das medidas de PA e FC nos períodos livres de dor (interictal) foram realizadas por meio de Medidas Residenciais da Pressão Arterial (MRPA) por quatro a cinco dias consecutivos, com a obtenção de seis medidas ao dia. Para a aquisição das medidas de PA e FC no período de dor da migrânea (ictal), os pacientes foram orientados a fazer MRPA a cada 10 minutos nas duas primeiras horas de dor e, após, a cada 15 minutos até o final da crise. Ainda, deveriam assinalar em um tipo de diário de cefaleia as características da dor a cada hora. Permitiu-se o uso de 400mg de ibuprofeno como tratamento de resgate após o final da segunda hora de dor. Para análise estatística, comparamos os valores de pressão arterial sistólica (PAS), pressão arterial diastólica (PAD), pressão arterial média (PAM) e FC realizadas no período interictal com as realizadas no período ictal. As variáveis obtidas durante a cefaleia foram comparadas em função da intensidade de dor e em função do uso de ibuprofeno. Resultados: As médias de PAS, PAD, PAM do período ictal foram significativamente menores que as do período interictal ( $\mathrm{p} \leq$ 0,01). Comparando as médias dos valores de PAS, PAD, PAM e FC do período interictal com as do período ictal divididas por hora para as primeiras quatro horas de dor, observamos que houve uma redução progressiva dos valores de PAS, PAD e PAM durante todo esse período ( $\mathrm{p} \leq 0,01)$. Quanto à FC, observamos que houve aumento de seus valores na primeira hora de dor $(\mathrm{p} \leq 0,02)$. Houve uma tendência de redução dos valores das médias de PAS, PAD e PAM nas dores de moderada e forte intensidade. Com relação ao ibuprofeno, não notamos diferenças nas variáveis. Conclusões: Durante a fase de dor da migrânea ocorre uma redução da PA desde a primeira hora de dor. Por outro lado, há um aumento dos valores da FC apenas na primeira hora de dor. Houve uma tendência de que os valores de PA reduzissem à medida que a dor progredisse de leve para moderada e forte intensidades. O uso de 400mg de ibuprofeno não promoveu alterações nas variáveis analisadas.

\title{
ESTUDO EPIDEMIOLÓGICO SOBRE SÍNDROME DAS PERNAS INQUIETAS E MIGRÂNEA
}

\author{
Karen dos Santos Ferreira \\ Orientador: Prof. Dr. Jose Geraldo Speciali \\ Dissertação de Mestrado apresentada em 13/08/2010
}

A Síndrome das Pernas Inquietas (SPI) é uma doença com sintomas sensitivos e motores com prevalência entre 2,5 e $10 \%$ na população caucasiana. Sua patofisiologia envolve uma disfunção do sistema dopaminérgico de neurotransmissores. A migrânea também é uma doença influenciada por mecanismos dopaminérgicos. Desenvolvemos um estudo para avaliar uma possível associação entre migrânea e SPI. Selecionamos os sujeitos entre funcionários do Hospital das Clínicas - Faculdade de Medicina de Ribeirão Preto - Universidade de São Paulo, Brasil. Pacientes com migrânea (n= 72) e controles pareados por sexo e idade $(n=72)$ foram incluídos e uma entrevista foi realizada baseada em um questionário estruturado. Foram avaliados os dados clínicos, demográficos, diagnóstico de SPI pelos critérios do Grupo Internacional para Estudo da Síndrome das Pernas Inquietas (GIESPI), Inventário de Depressão de Beck. SPI foi mais prevalente no grupo de migranosos que no grupo controle [25\% vs $8 \%$; $p=0,01$, odds ratio 3,67 $(1,36 ; 9,88)$ ]. Não houve significância na associação migrânea, SPI e outras comorbidades como diabetes, anemia, obesidade e uso de medicações, neste estudo. O tipo de migrânea (com e sem aura) e história familiar não foram diferentes entre os grupos com e sem SPI. As pontuações no Inventário de Beck (depressão) foram mais altas para os pacientes com migrânea em associação com SPI ( $\mathrm{p}=0,04)$.

\section{Oftalmologia, Otorrinolaringologia E Cirurgia De Cabeça E Pescoço}

\section{PAPEL DA DISLIPIDEMIA NA ESTRUTURA E FUNÇÃO DA GLÂNDULA LACRIMAL, GLÂNDULA DE MEIBOMIUS E SUPERFÍCIE OCULAR EM CAMUNDONGOS}

\author{
Carolina Maria Módulo \\ Orientador: Prof. Dr. Eduardo Melani Rocha \\ Dissertação de Mestrado apresentada em Defesa: 01/07/2010
}

Objetivo: ADislipidemia é definida pela presença de altos níveis de lipídios ou lipoproteínas no sangue e é causada pela combinação de fatores genéticos e ambientais. Prévios estudos mostraram conflitos na correlação entre a dislipidemia e a síndrome do olho seco. O objetivo do presente estudo foi investigar os achados funcionais e estruturais da síndrome do olho seco em animais dislipidêmicos com dieta normal ou dieta hiperlipídica. Métodos: Camundongos machos e fêmeas adultos ( $\mathrm{n}=5$ /grupo) que super-expressão a apoliproteína CIII (ApoCIII), knokout para ApoE (ApoEKO) com dieta normal 
e knokout para o receptor LDL com dieta normal (LDLRKO) e hiperlipídica (LDLRKO-hiper) foram comparados com seus respectivos controles C57BL/6. Os animais foram anestesiados e avaliados pelo teste do fenol vermelho, exame da córnea com lâmpada de fenda e citologia de impressão da córnea (CI). Amostras de sangue, da glândula lacrimal (GL), glândula de Meibomius (GM) e córnea também foram avaliadas. Resultados: O peso corpóreo foi maior em camundongos machos $(\mathrm{P}<0,05)$ quando comparados com as fêmeas. O peso corpóreo foi maior nos camundongos fêmeas controles do que nos camundongos fêmeas LDLRKO-hiper ( $\mathrm{P}=0.0043)$ e machos LDLRKO do que em fêmeas LDLRKO-hiper $(\mathrm{P}=0.0016)$. O peso da glândula lacrimal foi maior em camundongos machos LDLRKO ( $\mathrm{P}=0.0003)$, LDLRKO-hiper ( $\mathrm{P}<0.0001)$, ApoEKO ( $\mathrm{P}=0.0022)$ e Apo CIII ( $\mathrm{P}=0.0116)$ do que em suas respectivas fêmeas. $\mathrm{O}$ teste do fenol vermelho foi menor em camundongos machos LDLRKO-hiper do que em camundongos machos controle com dieta normal ( $\mathrm{P}=0.0273)$. Exame da córnea, CI e análises histológicas da GL, GM e córnea não mostram nenhuma diferença entre os grupos. Conclusões: Os presentes dados contradizem a hipótese de que a dislipidemia esteja envolvida com a síndrome do olho seco. Entretanto, o perfil da dieta associado ao aspecto genético e o sexo masculino tem impacto funcional na glândula lacrimal. Isto sugere que vários fatores estão envolvidos com a disfunção do filme lacrimal na dislipidemia.

\title{
AVALIAÇÃO AUDIOLÓGICA EM PACIENTES SUBMETIDOS AOS TRATAMENTOS RADIOTERÁPICO E QUIMIOTERÁPICO EXCLUSIVO OU COMBINADO
}

\author{
Ana Helena Bannwart Dell'Aringa \\ Orientador: Profa. Dra. Myriam de Lima Isaac \\ Dissertação de Mestrado apresentada em 23/07/2010
}

Introdução: Os métodos terapêuticos radioterapia e quimioterapia, realizados isoladamente ou em combinação, são efetivos tratamentos anti neoplásicos que visam a cura ou o prolongamento da vida. São muito conhecidos por seus efeitos tóxicos e dentre eles encontra-se a ototoxicidade para a droga cisplatina e para a radiação em região de cabeça e pescoço. Objetivos: Avaliar a funcionalidade do sistema auditivo em sujeitos que realizaram tratamento radioterápico em região de cabeça e pescoço e quimioterapia à base de cisplatina, tanto de maneira exclusiva como combinada. Métodos: No período de julho de 2006 a janeiro de 2008, 70 sujeitos foram submetidos a avaliações audiológicas (audiometria tonal limiar, imitanciometria e emissões otoacústicas por produto de distorção) pré e pós tratamento oncológico. Os sujeitos foram divididos em 3 grupos: Grupo A - (22) sujeitos que realizaram radioterapia exclusiva em região de cabeça e pescoço, Grupo B - (14) sujeitos que realizaram quimioterapia exclusiva à base de cisplatina e Grupo C - (34) sujeitos que realizaram radioterapia em região de cabeça e pescoço associada à quimioterapia à base de cisplatina. Resultados: Segundo os critérios da ASHA, a diminuição dos limiares auditivos tonais logo após o término do tratamento radioterápico, foram verificadas em $15,7 \%$ orelhas esquerdas e $26,3 \%$ orelhas direitas; após o tratamento quimioterápico $23,0 \%$ orelhas esquerdas e 7,6\% orelhas direitas apresentaram alteração e no tratamento combinado 70,0\% orelhas esquerdas e $60,0 \%$ orelhas direitas. A idade abaixo de 60 anos foi o único fator de risco que apresentou relação significativa para a alteração da audição, apenas no grupo que realizou o tratamento combinado. Quando realizada a análise comparativa entre os grupos, a adição do agente quimioterápico, cisplatina, ao tratamento de radioterapia, foi responsável pelo aumento dos limiares auditivos tonais. Conclusão: Os três métodos terapêuticos causaram alterações auditivas logo após o término do tratamento; o tratamento combinado foi o que apresentou maiores alterações; a adição da cisplatina ao tratamento radioterápico apresentou maior risco para a ototoxicidade.

\section{BEVACIZUMABE INTRAVÍTREO PARA O TRATAMENTO DO EDEMA MACULAR DIABÉTICO ASSOCIADO À PERDA CAPILAR GRAVE}

\author{
Marco Antonio Bonini Filho \\ Orientador: Prof. Dr. Rogério Alves Costa \\ Tese de Doutorado apresentada em Defesa: 03/08/2010
}

Objetivo: Avaliar os efeitos do bevacizumabe intravítreo no tratamento do edema macular diabético (EMD) associado à perda capilar grave. Desenho do Estudo: Estudo multicêntrico, aberto, não-aleatório. Métodos: Em dois centros de referência terciária em oftalmologia, dez pacientes consecutivos com diagnóstico de EMD associado à perda capilar grave foram submetidos a injeção intravítreo de bevacizumabe $(1,5 \mathrm{mg})$. Avaliação oftalmológica completa, tomografia de coerência óptica (TCO) e angiografia com fluoresceína foram realizadas na visita inicial e semanas 8, 16, 24 e 54. E, as medidas principais avaliadas foram as mudanças individuais na melhor acuidade visual corrigida (MAVC) e nas variáveis objetivas 
da TCO (espessura macular central [EMC] e volume macular total [VMT]). Resultados: A MAVC média (logMAR) foi de $0,786(20 / 125+1)$ na visita inicial, $0,646(20 / 80-2)$ na semana $8,0,580(20 / 80+1)$ na semana $16,0,574(20 / 80+1)$ na semana 24 , e $0,558(20 / 80+2)$ na semana 54. Melhora significativa na MAVC foi observada em todos os períodos estudados (P<0,008). Os valores médios de EMC $(\mu \mathrm{m})$ e VMT (mm3) foram respectivamente: 472,6 e 10,9 na visita inicial, 371,4 e 9,9 na semana 8, 359,5 e 9,8 na semana 16,323,9 e 9,4 na semana 24, e 274,6 e 8,7 na semana 54. Redução significativa do EMC e VMT foi observada nas semanas 24 e $54(\mathrm{P}<0.007)$. Na semana 54, observou-se redução do extravasamento de contraste em região macular bem como ausência de achados angiográficos sugestivos de qualquer progressão da perda capilar. Conclusão: Os resultados aqui apresentados, tanto na acuidade visual bem como variáveis mensuráveis da TCO, sugerem que o bevacizumabe intravítreo pode ser uma alternativa de tratamento viável para o manejo do edema macular diabético associado a perda capilar grave.

\title{
Ortopedia, Traumatologia E Reabillitação
}

\section{EFEITO DA UTILIZAÇÃO DE LIDOCAÍNA ENDOVENOSA EM INFUSÃO CONTÍNUA SOBRE O RELAXAMENTO MUSCULAR PRODUZIDO PELO ROCURÔNIO}

\author{
Gustavo Gameiro Vivancos \\ Orientador: Prof. Dr. Luís Vicente Garcia \\ Dissertação de Mestrado apresentada em 07/07/2010
}

Justificativa e Objetivos: A lidocaína interage na junção neuromuscular potencializando o efeito dos relaxantes musculares podendo diminuir a latência. Uma menor latências favorece a intubação orotraqueal em pacientes com estômago cheio e com risco de aspiração broncopulmonar. A lidocaína é também utilizada pela via endovenosa para bloquear a resposta hemodinâmica a intubação orotraqueal e diminuir os reflexos de via aérea, entretanto sua utilização é controversa. O presente estudo buscou determinar o efeito da administração de lidocaína sobre o latência do relaxante muscular rocurônio, indicado em intubação em sequência rápida, e sobre as alterações cardiovasculares provocadas pela IOT. Método: 80 pacientes do estado físico ASA I e II submetidos à cirurgia eletiva sob anestesia geral foram distribuídos casualmente em 4 grupos. Os pacientes dos grupos 1 e 2 receberam $0,6 \mathrm{mg} / \mathrm{Kg}$ de rocurônio na indução anestésica sendo que os do grupo 2 receberam $2 \mathrm{mg} / \mathrm{Kg}$ de lidocaína antes da indução. Já os pacientes dos grupos 3 e 4 receberam 1,2 mg/Kg de rocurônio sendo que os do grupo 4 receberam a mesma dose de lidocaína antes da indução. A latência do bloqueio neuromuscular foi medida através da aceleromiografia em padrão de estímulo simples de $1 \mathrm{~Hz}$ no músculo adutor do polegar. As pressões arteriais sistólica, diastólica e média e a frequência cardíaca foram medidas antes da indução e logo antes e um minuto depois da IOT. As variáveis hemodinâmicas foram analisadas em 2 grupos entre os paciente que receberam ou não lidocaína, independente da dose de rocurônio utilizada. Resultados e Conclusões: Não foi encontrada diferença estatisticamente significativa entre a latência do rocurônio nas doses de $0,6 \mathrm{mg} / \mathrm{Kg}$ e $1,2 \mathrm{mg} / \mathrm{Kg}$ nos pacientes que receberam ou não a lidocaína antes da indução anestésica. A latência dos pacientes que receberam rocurônio $0,6 \mathrm{mg} / \mathrm{Kg}$ com lidocaína foi estatisticamente igual à dos pacientes que receberam $1,2 \mathrm{mg} / \mathrm{Kg}$ de rocurônio, independente da administração ou não de lidocaína. Os pacientes que não receberam lidocaína antes da indução apresentaram aumentos dos valores de pressão arterial sistólica, diastólica e média e da frequência cardíaca após a IOT, o que não ocorreu nos que receberam lidocaína. Assim a lidocaína endovenosa antes da indução anestésica é capaz de atenuar a resposta hemodinâmica de taquicardia e hipertensão associadas às manobras de IOT, mas não de potencializar o bloqueio neuromuscular do rocurônio, diminuindo sua latência.

\section{DADOS NORMATIVOS DA EXCITABILIDADE NEUROMUSCULAR (CRONAXIA E ÍNDICE DE ACOMODAÇÃO) USANDO O EQUIPAMENTO NEMESYS 941 PARA OS MÚSCULOS ABDUTOR CURTO DO POLEGAR, EXTENSOR LONGO DO POLEGAR E FLEXOR CURTO DO V DEDO}

\author{
Márcio Innocentini Guaratini \\ Orientador: Prof. Dr. Nilton Mazzer \\ Tese de doutorado apresentada em 29/07/2010
}

Após a desnervação do músculo esquelético, os esforços terapêuticos para restaurar a funcionalidade dos nervos sempre envolvem uma preocupação em manter o tecido alvo da regeneração nervosa no melhor estado fisiológico possível 
até que a regeneração e a reinervação sejam completadas. A determinação das curvas i/T e dos valores de reobase, cronaxia, acomodação e coeficiente de acomodação (á) orientam a melhor forma de se estimular eletricamente um músculo desnervado. Dois métodos testam a excitabilidade elétrica do tecido nervoso e muscular, a eletroneuromiografia e o eletrodiagnóstico de estímulo. Eles são baseados no principio diagnóstico de diferentes parâmetros de excitabilidade do nervo e do músculo. A maioria dos testes eletrodiagnósticos empregados dependem de dados normativos para sua interpretação. O objetivo deste trabalho é construir um referencial de valores para os índices de excitabilidade neuromuscular, resultantes do eletrodiagnóstico de estímulo, os chamados pontos indicativos da excitabilidade: a análise da reobase, cronaxia, acomodação e coeficiente de acomodação (á). Foram avaliados 300 sujeitos normais, ou seja, sem lesão nervosa periférica, sendo 150 homens e 150 mulheres, com média de idade de 28,19 9 9,48 anos. Foram avaliados os músculos abdutor curto do polegar, extensor longo do polegar e flexor curto do $\mathrm{V}$ dedo inervados pelos nervos mediano, radial e ulnar respectivamente. Os dados cronaximétricos e de coeficiente de acomodação (á) são expressos em valores de média e intervalo de confiança a $95 \%(\mu<$ média $<\mu$ ). Os resultados para o valor da cronaxia do músculo abdutor curto do polegar foram $0,1882<0,1986<0,2089$; o valor de cronaxia para o músculo extensor longo do polegar foram $0,1914<0,2021<0,2129$; e o valor de cronaxia para o músculo flexor curto do $\mathrm{V}$ dedo foram $0,1904<0,2009<0,2113$. O valor do coeficiente de acomodação (á), expresso pelos limites do intervalo de confiança, para o músculo abdutor curto do polegar variou de 1,6 -2,8; o valor do coeficiente de acomodação (á) para o músculo extensor longo do polegar variou de 1,6 -2,9; e o valor do coeficiente de acomodação (á) para o músculo flexor curto do $\mathrm{V}$ dedo variou de 1,6-2,9. Os valores obtidos neste estudo podem ser tomados como valores normativos e utilizados como referencial clínico.

\title{
AVALIAÇÃO DA FORÇA INDIRETA DOS MÚSCULOS DO ASSOALHO PÉLVICO E SERERIDADE DE RELATOS DE INCONTINÊNCIA URINÁRIA EM GESTANTES COM DIABETES MELLITUS GESTACIONAL OU DE BAIXO RISCO E EM NÃO GESTANTES
}

\author{
Flaviane de Oliveira Souza \\ Orientadora: Profa.Dra. Cristine Homsi Jorge Ferreira \\ Dissertação de Mestrado apresentada em 16/08/2010
}

Introdução: Apesar de haver o reconhecimento da importância da força dos músculos do assoalho pélvico (MAP) na manutenção da continência urinária, não existem estudos que tenham avaliado estas variáveis em gestantes com diabetes mellitus gestacional. Objetivos: Avaliar a função dos MAP de mulheres grávidas com diabetes Mellitus gestacional (G-DMG), de baixo risco (G-BR), e não grávidas (NG). Métodos: Trata-se de um estudo clínico transversal que incluiu 143 mulheres, sendo 41 G-DMG, 60 G-BR e 42 NG. As grávidas foram avaliadas com 25 semanas de idade gestacional por meio da palpação vaginal com uso da escala de Oxford modificada, perineometria e entrevista utilizando-se o ICIQ. Na análise estatística foi utilizado o teste exato de Fisher, ANOVA, modelo linear de efeitos mistos. As análises foram feitas através do software SAS versão 9. Resultados: Os grupos foram homogêneos em relação a idade, índice de massa corporal (IMC), raça e paridade. Em todos os grupos houve um maior percentual de mulheres com escore 2 e 3 de AFA ( $p=0,38$ ). Os grupos também foram semelhantes em relação a perineometria, as G-DMG obtiveram média de pico de $40,15 \mathrm{cmH}_{2} \mathrm{O}$, G-BR $37,06 \mathrm{cmH}_{2} \mathrm{O}$ e NG 35,44 $\mathrm{cmH}_{2} \mathrm{O}$. Relataram pelo menos um episódio de incontinência urinária (IU) no último mês $56 \%$ das G-DMG, $53 \%$ das G-BR, e $52 \%$ das NG $(p=0,95)$. A severidade da IU e impacto na qualidade de vida foi leve para o grupo de NG e moderado para as G-BR e G-DMG. Conclusão: Não houve diferença entre os grupos quanto a força indireta dos MAP e taxas de relato de IU.

\section{FRATURAS EM 4 PARTES DO ÚMERO PROXIMAL: ANÁLISE BIOMECÂNICA DE 4 TIPOS DE OSTEOSSÍNTESE MÍNIMA}

\author{
Elpídio da Graça \\ Orientador: Prof.Dr. Cláudio Henrique Barbieri \\ Tese de Doutorado apresentada em 24/08/2010
}

As fraturas do úmero proximal são frequentes e seu diagnóstico e tratamento são desafiadores. O tratamento das fraturas em 4 partes do úmero proximal é controverso, porém recentemente existe uma maior tendência ao tratamento cirúrgico com osteossíntese mínima em pacientes ativos e com boa qualidade óssea. Existem diferentes tipos de implantes 
para a realização destas osteossínteses, porém sem nível de evidência suficiente para determinar o melhor tipo de osteossíntese. Conduzimos um trabalho experimental utilizando modelos de úmeros humanos confeccionados em poliuretana com objetivo de testar biomecanicamente qual técnica de osteossíntese apresentava melhor desempenho. Um tipo de fratura em 4 partes foi criado, e após fixação, tracionado através de tirantes. Foram analisados os resultados da rigidez relativa na fase elástica para testes de tração (adução) e torção (rotação externa) de quatro grupos de osteossíntese mínima: 1) placa DCP 3,5 mm (Schatzker), 2) parafusos diafisários 4,5 mm (Jakob modificada), 3) fios de kirschner 2,0 mm (Jakob) 4) parafusos corticais 3,5 mm (A0-ASIF), todos os grupos foram associados a cerclagem com fios de poliéster trançado entre os tubérculos. O resultado dos testes de tração (adução) mostrou para os respectivos grupos: 1) 1,121 \pm 0,33 N/mm, 2) 0,991 $\pm 0,178 \mathrm{~N} / \mathrm{mm}), 3$ ) 0,516 $\pm 0,159 \mathrm{~N} / \mathrm{mm}$ ) e, 4) 0,639 $\pm 0,157 \mathrm{~N} / \mathrm{mm}$; com diferença estatística (p<0,05) entre os grupos 1 e 3, 1 e 4; e, 2 e 3 . O resultado para os testes de torção (rotação externa) mostrou para os respectivos grupos: 1) $6,88 \pm 1,754 \mathrm{~N} /$ grau, 2) 9,792 \pm 1,542 N/grau, 3) 2,634 \pm 0,331 N/grau e, 4) 1,311 \pm 0,650 N/grau; com diferença estatística $(\mathrm{p}<0,05)$ entre os grupos 1 e 4, 2 e 3 e 2 e 4 . Com a análise dos resultados dos testes de tração (adução) e torção (rotação externa) concluiu-se que todos os grupos suportaram cargas caracterizadas como fisiológicas para o ombro; que os grupos de placa DCP (Schatzker) e parafuso diafisário 4,5 mm (Jakob modificado) apresentaram comportamento semelhantes com relação a rigidez porém com melhor desempenho para o grupo de placa DCP (Schatzker) que distribui melhor a concentração de tensão por todo seu comprimento e não apresentou falhas devido a quebra óssea. O modelo para estudo de fraturas em 4 partes do úmero proximal se mostrou viável.

\title{
Patologia Experimental
}

\section{INFLUÊNCIA DA ÓXIDO NÍTRICO SINTASE INDUZÍVEL NO DESENVOLVIMENTO DE ANEURISMA EM AORTA ABDOMINAL DE RATOS WISTAR: MODELO EXPERIMENTAL INÉDITO}

\author{
Paula Stramandinoli Prudente \\ Orientadora: Profa. Dra. Simone Gusmão Ramos \\ Dissertação de Mestrado apresentada em 08/07/2010
}

O presente trababalho teve por objetivo avaliar a atuação do óxido nítrico sintase induzível(iNOS), e das metaloproteinases (MMPs) 2 e 9 na indução de um modelo inédito de aneurisma da aorta abdominal (AAA) em ratos Wistar, utilizando duas causas potenciais de liberação de MMPs: lesão vascular externa na aorta e turbulência local do fluxo sanguíneo. Os animais foram divididos em 4 grupos: Grupo AAA (estenose extrínseca na aorta abdominal associada à lesão traumática da camada externa) e Grupo Sham(controle). Estes grupos foram duplicados: metade recebeu PBS e a outra metade $1400 \mathrm{~W}$, inibidor seletivo de iNOS.Pudemos notar que no grupo AAA houve formação de aneurisma em 60$70 \%$ dos animais (dilatação de 300\%) formados por um intenso remodelamento da parede arterial, caracterizado por importante resposta inflamatória composta principalmente de neutrófilos e macrófagos, destruição de fibras elásticas, proliferação mesenquimal com deposição de colágeno e neovascularização. A imunoistoquímica mostrou a participação efetiva do NO e das MMPs-2 e -9 no desenvolvimento dos aneurismas. O grupo tratado com 1400W não desenvolveu aneurismas em $83 \%$ dos animais. Esses resultados apontam para uma efetiva participação da iNOS, consequentemente do NO, e das MMPs 2 e 9 na formação de AAAs nesse modelo experimental.

\section{Saúde da Criança e do Adolescente}

\section{FATORES DE RISCO E MORTES INFANTIS EVITÁVEIS EM COORTE DE BASE POPULACIONAL, ARACAJU / SE / BRASIL}

\author{
Maria Pontes deAguiar Campos \\ Orientador: Prof. Dr. Marco Antonio Barbieri \\ Tese de Doutorado apresentada em 13/07/2010
}

Contexto:o Coeficiente de Mortalidade Infantil (CMI) expressa o risco de um nascido vivo (NV) morrer antes de completar um ano de vida. É considerado um dos mais sensíveis indicadores de saúde e, por conseguinte, da qualidade de vida de uma população. Em Aracaju / SE esse coeficiente vem apresentando tendência decrescente, embora permanecendo 
acima da média nacional. Objetivos: analisar a mortalidade infantil em coorte de nascimento realizada em Aracaju / SE / Brasil em 2005, hierarquizar os fatores de risco para a mortalidade infantil e neonatal relativos aos indicadores demográficos, biológicos e socioeconômicos da mãe e do recém - nascido e caracterizar as causas dos óbitos infantis nesse município. Métodos: observacional, analítico, que vinculou os nascimentos de crianças vivas entre 08 de março a 15 de julho de 2005. Inicialmente, os efeitos dos fatores foram avaliados individualmente, comparando-se os seus níveis por meio do teste de Fisher. Para análise dos fatores de risco foi utilizado o modelo de análise multivariada, assumindose intervalos de confiança de 95\%. Resultados: o CMI, na grande Aracaju, foi de 21,23/1000 NV e o Coeficiente de Mortalidade Neonatal (CMN) de 16,18 mortes / 1000 NV. As variáveis que apresentaram maiores associações com as mortalidades estudadas foram: peso ao nascer, duração da gestação e Restrição do Crescimento Intra Uterino (RCIU). Na análise ajustada, quando se utilizou a RCIU (RR 7,64, IC de 95\% 4,66 - 12,52 e RR 8,88, IC de 95\% 5,05 - 15,42) como variável explicativa, o risco associou-se à mortalidade infantil e neonatal respectivamente com: ausência de pré-natal (RR 2,78, IC 95\% 1,29- 5,97 e RR 3,43, IC 95\% 1,57 - 7,52); situação conjugal sem companheiro (RR 1,67, IC 95\% 1,06 - 2,62 e RR 2,03, IC 95\% 1,22 - 3,38) história de natimorto anterior (RR 3,72, IC 95\% 1,99 - 6,96e RR 3,96 IC 95\% 1,97 - 7,96) e consumo de álcool na gravidez (RR 1,72, IC 95\% 1,10 - 2,67 e RR 1,97, IC 95\% 1,20 - 3,25). Quando se utilizou como variável explicativa duração da gestação apenas natimortalidade prévia (RR 2,19 IC 95\% 1,18 - 4,05 e RR 2,20, IC 95\% 1,11 - 4,34) permaneceu como fator de risco. Quando foi utilizado o peso ao nascer nenhuma das variáveis de ajustamento permaneceu significante. Dos óbitos ocorridos na grande Aracaju, no ano de 2005, em crianças menores de um ano, 87,1\% são considerados evitáveis. Apresentaram maior proporção os óbitos reduzíveis por "adequada atenção à mulher na gestação" com 47,5 \%, seguidos de "adequada atenção ao RN" com 17,9\%. Conclusões. Os achados refletem um CMI classificado como médio. Peso ao nascer, duração da gestação e RCIU foram variáveis fortemente associadas como fatores de risco para as mortalidades estudadas. Os fatores de risco identificados são passíveis de intervenção e devem ser imediatamente enfrentados objetivando uma melhora da assistência pré-natal, parto e ao RN.

\title{
AVALIAÇÃO DO ESTADO NUTRICIONAL DOS PACIENTES COM DIAGNÓSTICO DE SÍNDROME NEFRÓTICA IDIOPÁTICA DA INFÂNCIA POR MEIO DA ANÁLISE VETORIAL DE IMPEDÂNCIA BIOELÉTRICA
}

\author{
Audrey Silva dos Santos \\ Orientador: Prof. Dr. José Simon Camelo Junior \\ Dissertação de Mestrado apresentada em 02/08/2010
}

A Síndrome Nefrótica Idiopática da Infância, ou Nefrose, é caracterizada por proteinúria intensa e persistente, causando edema em crianças de um a dez anos de idade. Geralmente responde à terapia com corticosteróides e a evolução é benigna. Pode ocorrer desnutrição aguda durante as crises, sendo necessário um método de avaliação nutricional adequado.

A análise vetorial de impedância bioelétrica (BIVA) permite avaliar a criança por medidas diretas de impedância vetorial e não depende de equações ou modelos. Na BIVA, resistência e reactância, padronizadas para o comprimento, são ponteadas como pontos vetoriais. Quando avaliados graficamente, após padronização para estatura, diferentes condições aparecem para formar grupos distintos, combinando estados de hidratação e nutricional em quatro diferentes quadrantes.

Objetivo: Avaliar o estado nutricional de crianças com diagnóstico de Nefrose em pelo menos dois tempos distintos: na crise e na remissão, utilizando a análise vetorial de impedância bioelétrica e ângulo de fase.

População Estudada e Métodos: Foi realizado um estudo prospectivo com 38 crianças com diagnóstico de Síndrome Nefrótica Idiopática da Infância, de três a treze anos de idade, em acompanhamento no ambulatório de Nefrologia Pediátrica do Hospital das Clínicas de Ribeirão Preto, de outubro de 2007 a outubro de 2008. As crianças foram submetidas a exame antropométrico e de bioimpedância elétrica em dois momentos: na crise nefrótica e na remissão.

Resultados: Houve caracterização de subnutrição aguda em 65\% das medidas durante episódio de edema e em 11,8\% durante a remissão da doença. Foi realizada uma avaliação de sobrevida livre de doença por Kaplan-Meier com relação à recuperação do ângulo de fase entre as duas medidas (ângulo de fase remissão menos ângulo de fase edema). Foi observado que uma recuperação do ângulo de fase maior ou igual a $0,5^{\circ}$ teve uma relação direta com a sobrevida livre de doença, ou seja, as crianças que recuperaram ao menos $0,5^{\circ}$ no valor do ângulo de fase tiveram um tempo maior sem recidivas.

Conclusão: O presente estudo demonstrou a ocorrência de subnutrição aguda em pacientes com Síndrome Nefrótica Idiopática da Infância durante episódio de edema e a sua recuperação, na grande maioria dos casos, na remissão. Parece haver relação entre a recupera9ao no angulo de fase (remissão menos edema) e a sobrevida livre de doen9a (tempo sem recidivas). São necessários mais estudos em crianças para validar a hipótese. 


\title{
Saúde Mental
}

\section{ESTUDO SOBRE ALTERAÇÕES NEUROFUNCIONAIS APÓS INGESTÃO DE AYAHUASCA}

\author{
Joel Porfírio Pinto \\ Orientador: Prof. Dr. Jaime Eduardo Cecílio Hallak \\ Dissertação de Mestrado apresentada em 24/09/2010
}

\begin{abstract}
A Ayahuasca é um chá originário da Amazônia e utilizado por igrejas sincréticas brasileiras. Composto pela fervura das folhas da Psychotria sp com pedaços da planta Banisteriopsis sp, contém o alucinógeno de meia-vida curta Dimetiltriptamina, agonista $5 \mathrm{Ht} 2 \mathrm{~A}$, e $\beta$-carbolinas, inibidores da Monoaminoxidase. Já foi demonstrado que a Ayahuasca é capaz de gerar estados alterados da consciência acompanhados de alteração da percepção, tendo sua utilização, inclusive, sido proposta como modelo para psicoses. Objetivos: Avaliar as alterações agudas do fluxo sanguíneo cerebral (FSC) ocasionadas pela ayahuasca e a modulação da atividade cerebral durante tarefa de fluência verbal durante sua ação. Metodologia: Realizados dois estudos com voluntários saudáveis. No primeiro avaliaram-se as alterações do FSC, através de SPECT, em dez voluntários sem uso prévio da ayahuasca, em duas sessões em repouso, separadas por uma semana no mínimo, diferidas pela ingestão do chá $(200 \mathrm{ml})$. No segundo, dez usuários ritualísticos foram submetidos a duas sessões semelhantes de RMF, nas quais se solicitou uma tarefa de fluência verbal com a geração mental de palavras iniciadas com as letras "F","A" e "S". Em uma das sessões, os voluntários ingeriram o chá (150ml). Resultados: As alterações comportamentais foram semelhantes nos dois experimentos, com alterações sensoperceptivas, do processo de pensamento e elevação do humor/afeto, sem perda do contato com a realidade. No experimento do SPECT, houve ativação do córtex frontal, temporal e de áreas límbicas. Também foi observada redução do FSC em região do hemisfério cerebelar direito. No estudo com RMF foi observada diminuição da ativação de áreas relacionadas à linguagem, com diminuição da lateralização hemisférica fisiológica durante a tarefa de geração de palavras. Essas alterações foram anteriormente relacionadas com transtornos psicóticos e com estados alterados de consciência induzidos por substâncias. Conclusões: A modulação cerebral relacionadas à ayahuasca parece útil no estudo da neurobiologia das psicoses, embora haja diferenças entre estas e o estado induzido pela substância.
\end{abstract}

\section{A QUESTÃO DO GÊNERO NA AVALIAÇÃO DA EFICÁCIA DE INSTRUMENTOS DE DETECÇÃO DE USO NOCIVO DE ÁLCOOL EM UM ESTUDO POPULACIONAL NA REGIÃO METROPOLITANA DE SÃO PAULO - UM RECORTE DO PROJETO GENACIS}

\author{
Janaina Barbosa de Oliveira \\ Orientador: Prof. Dr. Jair Lício Ferreira Santos \\ Tese de Doutorado apresentada em 28/09/2010
}

Tendo em vista os diversos problemas associados, o uso de risco de álcool é considerado uma relevante questão de saúde pública. Uma das estratégias de prevenção primária e/ou secundária recomendada é a utilização dos instrumentos de rastreamento associados às intervenções breves em serviços de atenção primária à saúde. Muitos instrumentos de rastreamento têm sido desenvolvidos para auxiliar na detecção precoce dos problemas causados pelo consumo de risco de álcool, tornando possível evitar a identificação de problemas apenas quando estes já se tornaram crônicos. Mas o desempenho desses instrumentos tem sido avaliado mais frequentemente em contexto clínico, pouco se conhece sobre sua eficácia na população geral. O objetivo geral deste trabalho foi comparar a eficácia dos instrumentos CAGE, TWEAK e T-ACE, de mais fácil e rápida aplicação, com o AUDIT (padrão-ouro), segundo gênero e faixa etária. O presente estudo é uma comparação de instrumentos de rastreamento realizado a partir dos dados de um inquérito epidemiológico transversal em amostra estratificada e representativa. É um recorte do projeto GENACIS, realizado na região metropolitana de São Paulo, cuja amostra totalizou 2083 pessoas maiores de 18 anos. A coleta de dados foi feita através de aplicação do questionário GENACIS em entrevistas individuais nos domicílios sorteados. Foram avaliados a sensibilidade (S), especificidade (E), valores preditivos positivo (VPP) e negativo (VPN), área sob a curva ROC (Receiving Operating Characteristic - ASC ROC) e os respectivos intervalos de confiança para cada instrumento. Os resultados foram comparados pelos testes usuais de proporções, por meio da distribuição binomial ou de aproximação normal. Um teste de associação que corrige para o efeito do desenho amostral (Teste de Rao-Scott, Intervalos de Confiança de 95\%) foi utilizado na análise univariada. 
Em todas as análises foi fixado como probabilidade de ocorrência do erro de primeira espécie o valor alfa de 5\%. A taxa de resposta foi de $74,9 \%$. Houve predominância de mulheres $(58,4 \%)$, indivíduos casados $(60,8 \%)$, renda per capita inferior a 150 Reais $(37,9 \%)$, mulheres abstinentes $(69,7 \%)$ e homens com consumo pesado de álcool $(24,2 \%)$. Os abstinentes aumentaram conforme a idade e o consumo pesado apresentou-se maior entre os mais jovens. Os escores do AUDIT referentes a consumo de baixo risco foram mais prevalentes entre as mulheres $(97,2 \%)$ e os demais escores foram maiores para os homens. A maioria dos escores do AUDIT foram maiores entre os mais jovens ( 18 a 29 anos de idade) em ambos os gêneros, com exceção dos escores entre 20 e 40, que foram mais prevalentes entre homens de 40 a 49 anos (40,2\%) e 30 a 39 anos de idade $(32,4 \%)$. Em comparação com o AUDIT, com o aumento do ponto de corte (PC) dos instrumentos, em geral observou-se o aumento da E em até 50\% e a diminuição da S em até 100\%. Entre homens de todas as idades, o T-ACE foi mais eficaz (ASC ROC 0,92). Apresentaram diferença estatisticamente significante o TWEAK entre homens de 18 a 29 anos de idade (ASC ROC 0,92) e o T-ACE entre os homens de 30 a 39 anos (ASC ROC 0,90) e de 40 a 49 anos de idade (ASC ROC 0,92). Para as mulheres, apresentaram diferença estatisticamente significante o TWEAK entre as de 18 a 29 anos (ASC ROC 0,93 ) e o T-ACE entre mulheres de 30 a 39 anos de idade (ASC ROC 0,92). O CAGE teve a menor ASC ROC em todas as faixas etárias em ambos os gêneros. A maioria dos estudos compara o desempenho desses instrumentos em populações especiais, em tratamento ou unidades básicas de saúde. Comparar instrumentos de detecção em amostra populacional representativa pode melhor elucidar sua aplicabilidade no rastreamento precoce dos problemas relacionados ao álcool na população geral.

\title{
Saúde na Comunidade
}

\section{NA COSTURA DO SAPATO, O DESMANCHE DAS OPERÁRIAS: UM ESTUDO DAS CONDIÇÕES DE TRABALHO E SAÚDE DAS PESPONTADEIRAS DA INDÚSTRIA DE CALÇADOS DE FRANCA (SP)}

\author{
Taísa Junqueira Prazeres \\ Orientadora: Profa. Dra. Vera Lúcia Navarro \\ Dissertação de Mestrado apresentada em 05/07/2010
}

O mundo do trabalho, nas últimas décadas, foi palco de grandes transformações organizacionais e tecnológicas que modificaram os processos e as relações de trabalho, resultando no aumento dos contratos precários e temporários e na intensificação da jornada de trabalho, aliada à depreciação salarial e à exploração do trabalho em domicílio. Nesse contexto, observa-se um significativo aumento de adoecimentos relacionados ao trabalho e suas precárias condições, que atingem principalmente a classe trabalhadora feminina, devido às características e qualidade do trabalho a ela destinado. A escolha do trabalho na indústria calçadista francana como objeto de estudo deveu-se ao fato de nesta atividade se observar facilmente o resultado dessas mudanças, em especial na seção de costura mecânica (pesponto), onde há maior emprego de mulheres. Tendo como pano de fundo este contexto de mudanças, o objetivo dessa pesquisa foi investigar o trabalho de mulheres que realizam tarefas de pesponto de calçados em unidades produtivas de diferentes portes, no município de Franca e tentar estabelecer relações entre as condições de trabalho e os problemas de saúde por elas relatados. A pesquisa, de cunho qualitativo, teve como principal técnica de coleta de dados a entrevista. Foram realizadas 30 entrevistas com trabalhadoras, o que permitiu reconstituir o processo de trabalho e relacionar as condições de trabalho com os problemas de saúde relatados. A análise dos dados da pesquisa denunciou um efeito nefasto do trabalho das pespontadeiras em sua saúde, caracterizado por sofrimentos de ordem física, como fortes dores no corpo, lesões por esforços repetitivos e outros sofrimentos decorrentes das más condições de seus trabalhos, e também de ordem psíquica, como estresse, tristeza, irritação, ansiedade, além de sentimentos de insatisfação e desvalorização no trabalho, sendo que tais sofrimentos, somados às demais consequências de seus trabalhos esvaziam o sentido da vida em todas as esferas do cotidiano, possibilitando a compreensão do preço pago por essas trabalhadoras na busca de sobrevivência. Essa realidade mostrou-se ainda mais agravante quando a atividade laboral é realizada fora do espaço fabril, pela precarização das condições desta, passando esse sofrimento, a coexistir com outros problemas invisíveis do ponto de vista epidemiológico, mas maléfico à vida e à saúde dessas mulheres que vivem nesta situação. 